\title{
A new mechanistic understanding of ecophysiological patterns in a widespread alpine dwarf shrub-Refining climate-growth relationships
}

\author{
Svenja Dobbert ${ }^{1}$, Roland Pape ${ }^{2}$, Jörg Löffler ${ }^{1}$ \\ ${ }^{1}$ Department of Geography, University of Bonn, Meckenheimer Allee 166, D -53115 Bonn, Germany \\ ${ }^{2}$ Department of Natural Sciences and Environmental Health, University of South-Eastern Norway, Gullbringvegen 36, N- \\ 3800 Bø, Norway \\ Correspondence to: Jörg Löffler (joerg.loeffler@uni-bonn.de)
}

10 Abstract. Considering the recent widespread greening associated with dwarf shrubs in arctic and alpine ecosystems, further understanding of how these shrubs respond to environmental conditions is of crucial importance. Here we present novel insights and propose a new method to monitor shrub growth, using high-precision point dendrometers.

We analyzed intra- and inter-annual growth patterns of a common evergreen species (Empetrum nigrum ssp. hermaphroditum) by measuring its hourly radial stem variability at a micrometer scale over four successive years on exposed

15 ridge positions and along a steep elevational gradient. With the same temporal resolution, we collected near-ground microenvironmental data and identified environmental drivers controlling growth behavior.

Overall, we found high inter-plant variability in growth-defining parameters, but high similarities in growth responses to the micro-environment. Early-season radial growth in spring exhibited high sensitivity to winter thermal conditions and prolonged ground-freezing in spring, suggesting that the evergreen species E. hermaphroditum remains photosynthetically

20 active during the snow-free period, which increases carbohydrate accumulation for early season physiological activities. We discovered a phase of radial stem shrinkage during the winter months, which can be attributed to an active cell water reduction to protect the plant from frost damage.

We present the first fine-scale intra-annual growth curves for an alpine dwarf shrub and identify soil moisture availability and winter freezing conditions as the main drivers of radial stem variability, thus forwarding the ongoing debate on the

25 functional mechanisms of greening and browning in arctic and alpine regions. 
https://doi.org/10.5194/bg-2021-99

Preprint. Discussion started: 10 May 2021

(c) Author(s) 2021. CC BY 4.0 License.

(c) (i)

\section{Introduction}

Arctic and alpine ecosystems are especially sensitive to recent climate variability, with temperatures increasing twice as much as the global average in the past decades, accompanied by rising values of atmospheric $\mathrm{CO}_{2}$ and lengthening of the growing period (e.g., Stocker, 2013). This trend has favored growth, abundance, and biomass production of numerous shrub

30 species, resulting in widespread, yet spatially heterogenic, greening of the affected areas with potentially global effects (Myers-Smith et al., 2011; Gough et al., 2015; Brodie et al., 2019; Myers-Smith et al., 2020). The observed greening has been verified using remote sensing techniques (Carlson et al., 2017) and is caused by both evergreen and broadleaved species, although in different ways (Vowles and Björk, 2019; Weijers and Löffler, 2020). In general, shrubs are considered one of the most responsive plant functional groups to climate variability (Elmendorf et al., 2012), and their expanding trend,

35 in turn, has been associated with climatic feedbacks, such as influence on surface albedo and frozen-ground processes (Sturm et al, 2001; Chapin et al., 2005; Blok et al., 2011). Therefore, an understanding of shrub growth-physiology and its micro-environmental drivers in these highly sensitive ecosystems is of crucial importance, and dendroecological studies on shrubs have become increasingly important over the past decade.

40 In recent years, temperatures and soil moisture have been identified as the most important drivers in controlling shrub growth, with the highest effects caused by conditions during the growing season (Elmendorf et al., 2012; Hollesen et al., 2015; Ackerman et al., 2017; Weijers et al., 2017) and within the current year (Van der Wal and Stien, 2014). Additionally, most recent studies have suggested that snow cover and winter warming may play an important role in promoting shrub growth (Hollesen et al., 2015; Weijers et al. 2018b; Francon et al., 2020), as well as spring warming (Weijers et al., 2018b).

45 Yet, an increased frequency of spring freezing events might counteract these positive effects (Choler, 2018). Collectively, these studies agree on the fine-scale complexity of growth behavior, niche shifts, and local adaptation of shrubs in arctic and alpine regions, with a multitude of still little-understood site-related micro-environmental drivers (Graae et al., 2017; Pape and Löffler, 2017; Löffler and Pape, 2020).

50 High resolution data as provided by dendrometer measurements has the potential to bridge this knowledge-gap and provide valuable insights into fine-scale response mechanisms in a changing environment. In tree physiology and forest sciences, dendrometers have proven to be useful measurement devices for such fine-scale monitoring of tree responses to environmental fluctuations (Breitsprecher and Bethel, 1990; Duchesne et al., 2012; Ježík et al., 2016; Van der Maaten et al., 2018; Smiljanic and Wilmking, 2018), because dendrometers can detect radial stem dimensions at hourly or even shorter intervals (Drew and Downes, 2009; Liu et al., 2018). Starting with the early designs first described in the 1930s and the 1940s (Reineke, 1932; Daubenmire, 1945), they have been widely used to monitor tree growth, focusing on long-term monitoring of growth responses to environmental variables (e.g., Duchesne et al., 2012; Liu et al., 2018; Van der Maaten et al., 2018), and recently a study using band-dendrometers to monitor radial stem growth of tree-like shrubs was presented 
https://doi.org/10.5194/bg-2021-99

Preprint. Discussion started: 10 May 2021

(c) Author(s) 2021. CC BY 4.0 License.

(c) (i)

(González-Rodríguez et al., 2017). Because current dendrometers can measure at a micrometer scale, they have the potential

60 to be used on shrubs to provide fine-scale, intra-annual, continuous, and highly comparable information. Past studies, the first of which were published in 2006 and 2007 (Bär et al., 2006; Bär et al., 2007), had to rely solely on shrub-ring series (Macias-Fauria, et al., 2012; Shetti, 2018; Le Moullec et al., 2019), extraction of micro-cores, and wood anatomical analyses (Rossi et al., 2006; Weijers et al., 2010; Liang et al., 2012; Francon et al., 2020). Because trees and shrubs are both woody plants, such methodical transfers have proven successful in the past (e.g., Bär et al., 2006; Liang et al., 2012; Macias-Fauria

65 et al., 2012). Yet, they may have to be adapted for the special morphology, growth behavior and high internal variab ility of multi-stemmed shrubs (Bär et al., 2007; Buras and Wilmking, 2014; Myers-Smith et al., 2015). However, there are several insights to be gained. Because cambial activity occurs at time scales ranging from hours to days (Deslauriers et al., 2007; Köcher et al., 2012; Liu et al., 2018), the fine temporal resolution has the potential to provide valuable additional insights compared to traditional methods, including intra-annual and seasonal growth behavior of shrubs in alpine environments,

70 thereby filling in existing knowledge gaps regarding plant productivity in remote ecosystems (Le Moullec et al., 2019).

Additionally, the time series derived from dendrometer measurements of the stem radius offer information not only on radial stem growth but also on stem water relationships with higher quality and resolution than previously attainable (Fritts, 1976; Steppe et al., 2015; Zweifel, 2016; González-Rodríguez et al., 2017). Radial increase can be a result of both swelling tissue

75 (caused by induced water) and one-directional growth, and both can contain valuable information on cambial activity and shrub responses to external factors. Thus, it can be considered one of the strengths of this approach that these factors are both visible in the data and can be simultaneously assessed (Drew and Downes, 2009; Chan et al., 2016; Zweifel, 2016). Monitoring these inter-annual patterns could provide the opportunity to study fine-scale, inter-annual, eco-physiological mechanisms for the first time in shrubs. What has become a widely used practice in dendroecological studies on trees

80 (Deslauriers et al., 2007) has the potential to become available for shrubs as well and thus provide additional opportunities to gain novel insights into those plant communities with high relevance for potential global environmental change.

In this context we monitored intra- and inter-annual variability of stem radial variations of dwarf shrubs in an alpine environment, testing this novel approach using high-precision point-dendrometer data derived from dwarf shrubs to 1) 85 explain major growth patterns and their variation between years and specimens, 2) identify the most important microenvironmental drivers controlling these patterns, and 3) gain insights into potential response to environmental change. The main objective of our work is thus to gain detailed understanding of the mechanistic adaptation of one common arctic-alpine dwarf shrub (Empetrum nigrum ssp. hermaphroditum) to its micro-environment. With this we hope to bridge the gap between observed large-scale vegetational shifts, and the fine-scale physiological mechanisms driving these complex 90 changes within the highly relevant arctic-alpine ecosystems. 
https://doi.org/10.5194/bg-2021-99

Preprint. Discussion started: 10 May 2021

(c) Author(s) 2021. CC BY 4.0 License.

(c) (i)

\section{Material and Methods}

\subsection{Study sites}

We conducted our study in two alpine mountain regions of central Norway. To the west, the Geiranger/Møre og Romsdal region $\left(62^{\circ} 03^{\prime} \mathrm{N} ; 7^{\circ} 15^{\prime} \mathrm{E}\right)$ is located within the slightly to markedly oceanic climatic section (O1-O2; Moen, 1999) of the inner fjords. It is characterized by humid conditions, with total annual precipitation of 1,500-2,000 $\mathrm{mm}$ in the valleys (Aune, 1993 ) and a mean annual ambient air temperature of $1.9{ }^{\circ} \mathrm{C}$ (range: $-23.2{ }^{\circ} \mathrm{C}-17.2{ }^{\circ} \mathrm{C}$ ) (Löffler, 2003). To the east, the Vågåmo/Oppland region $\left(61^{\circ} 53^{\prime} \mathrm{N} ; 9^{\circ} 15^{\prime} \mathrm{E}\right)$ is located within the continental climatic section (C1; Moen, 1999). The total annual precipitation is low, approximately $300-500 \mathrm{~mm}$ in the valleys (Kleiven, 1959) and the mean annual ambient air temperature is $-1.2{ }^{\circ} \mathrm{C}$ (range: $-29.2{ }^{\circ} \mathrm{C}-16.7{ }^{\circ} \mathrm{C}$ ) (Löffler, 2003). Our own measurements indicated that the annual liquid

100 precipitation was $900 \mathrm{~mm}$ in the west and $375 \mathrm{~mm}$ in the east. The additional amount of solid precipitation and its snow water equivalent remains unknown, but snowdrift leads to an uneven distribution of the snowpack within the complex alpine topography (Löffler, 2007).

Across both regions, we used exposed alpine ridge sites that were randomly stratified based on elevational gradients within

105 the framework of our long-term alpine ecosystem research project (LTAER; e.g., Löffler and Finch, 2005; Hein et al., 2014; Frindte et al., 2019). The elevational gradient was stratified into six elevational levels from the tree line upwards, shifted by $100 \mathrm{~m}$ between regions to account for slightly different conditions and the position of the tree line. In the oceanic region, we used 900, 1000, 1100, 1200, 1300, and $1400 \mathrm{~m}$ a.s.l. (above sea level). In the continental region, we used 1000, 1100, 1200, 1300, 1400, and $1500 \mathrm{~m}$ a.s.l. The micro-topographical position at the ridges likely represented the most extreme thermal

110 regimes, with discontinuous snow cover and deeply frozen ground during winter. Our study design resulted in a total of two regions $\times$ six elevational levels $=12$ sites, with one specimen per site $(\mathrm{N}=12)$, and $12 \times$ four years $=48$ annual dendrometer curves. A summary of total stem diameter variation measured at each site is presented in Fig. A1.

\subsection{Species and specimens}

In this study, we focused on the dwarf shrub species Empetrum nigrum ssp. hermaphroditum (hereafter E. hermaphroditum),

115 which is abundant in the Scandes mountain chain. E. hermaphroditum is a common evergreen shrub that is almost circumpolar in distribution (Bell \& Tallis, 1973) and has been identified as a niche constructor species with strong direct effects on tundra communities, including a potential slowing of process rates and lowering of biodiversity with $E$. hermaphroditum encroachment (Bråthen et al., 2018). Because of its complex response to variation in snow cover, it is most common at positions with either shallow or relatively deep snow (Bienau et al., 2014; Bienau et al., 2016). Additionally, E.

120 hermaphroditum is comparatively resistant to low winter temperatures (Stushnoff and Junttila, 1986; Ogren, 2001). Löffler and Pape (2020) found its occurrence promoted by temperatures of $>15.5^{\circ} \mathrm{C}$ in the shoot zone and $>0.7{ }^{\circ} \mathrm{C}$ in the root zone. 
https://doi.org/10.5194/bg-2021-99

Preprint. Discussion started: 10 May 2021

(c) Author(s) 2021. CC BY 4.0 License.

(c) (i)

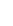

Generally, the species occurs in a wide phytogeographic range at various sites along the alpine elevational gradient. Its frequency is high at different micro-topographic positions and at high elevations the species occurs as the only exclusive dwarf shrub between a matrix of debris and graminoids. E. hermaphroditum was the first shrub species for which a chronology was successfully derived using its annual growth rings (Bär et al., 2007).

\subsection{Dendrometric data and monitoring setup}

Here, we applied a technological approach, commonly used for trees, to our multi-stemmed specimens of $E$. hermaphroditum, taking radial stem measurements using point dendrometers. The general idea was to use well-tested methods from dendroecology and tree growth analysis in a novel setting to further assess intra- and inter-annual variation in seasonal growth patterns and micro-environmental drivers. We mounted our dendrometers on one major above-ground stem horizontal to the ground surface on randomly chosen specimens, which were as close to the assumed root collar as possible. We avoided specific micro-positions near stones and depressions, inside the radius of other larger shrub species, and near patches of wind erosion (Fig. A2). Stem diameter data were measured at 1 min intervals using dendrometers (type DRO; Ecomatik, Dachau/Germany), where the temperature coefficient of the sensor was $<0.2 \mu$ m. Because we were interested in

135 seasonal patterns, we chose to eliminate the effects of daily short-term stem-size fluctuations from the dendrometer time series, for which there are commonly used approaches (Deslauriers et al., 2007). In accordance with our data we chose the “daily mean approach", averaging hourly dendrometer data using the 'dendrometeR' package (Van der Maaten et al., 2016), developed for the R statistical software (R Development Core Team, 2020).

\subsection{Analysis of seasonal growth patterns}

140 To assess inter-annual differences in seasonal growth and intra-annual growth patterns, we defined critical parameters and dates of stem growth phenology, such as a) total annual growth, defined as growth-induced irreversible stem expansion $(\mathrm{GRO}), \mathrm{b})$ peak growth (maximum daily growth rate), c) growth initiation (start of the growing season), d) growth cessation (end of the growing season), and e) peak shrinking during the winter months. To separate GRO from water-related expansion and contraction caused by hydrological processes, we first excluded reversible shrinking and swelling associated with the

145 stem water deficit from the original data using the approach proposed by Zweifel (2016). Assuming zero growth during periods of stem shrinkage, the final growth curve was derived from the original measured data by calculating the cumulative maxima (Zweifel et al., 2014; Zweifel, 2016). The respective dates were derived from sigmoid Gompertz models fitted to these estimations. Although multiple models have been used to describe growth, the Gompertz equation is the most widely used in dendrochronological studies and explains the variations in dendrometer measurements (for trees) (e.g., Rossi et al.,

150 2003; Rossi et al., 2006; Duchesne et al., 2012; Van der Maaten et al., 2018; Liu et al., 2019). The equation used for the model was Eq (1):

$y(t)=\alpha \times \exp (-\beta \times \exp (-k \times t)$ 
https://doi.org/10.5194/bg-2021-99

Preprint. Discussion started: 10 May 2021

(c) Author(s) 2021. CC BY 4.0 License.

(c) (i)

(1)

where alpha is the upper asymptote, beta is the $\mathrm{x}$-axis placement parameter, and $\mathrm{k}$ is the growth rate. We calculated these input parameters from our original data using the equations defined by Fekedulegn et al. (1999). To assess how well the models fit our data, we calculated a goodness-of-fit (GoF) measure using the least-squares method with the formula Eq (2): $\mathrm{GoF}=1-\left(\Sigma(\mathrm{f}-\mathrm{f} 2)^{2} / \Sigma \mathrm{f}^{2}\right.$

(2)

where $f$ is the original and $f 2$ is the modeled stem radius.

160

We determined growth initiation (onset) and cessation (offset) from this modeled curve to ensure that the main growth phase was being captured. Both dates were defined as the time when $20 \%$ and $90 \%$ of the total annual modeled growth occurred, respectively. We chose these thresholds following careful testing and, in accordance with our data, they were slightly higher than the thresholds used in similar studies for trees (e.g., Van der Maaten-Theunissen et al., 2013; Van der Maaten et al.,

165 2018; Drew and Downes, 2018). We first calculated these growth-defining parameters for each curve to assess the variability between sampled specimens.

Some of our specimens did not experience any growth or irreversible stem expansion in specific years. Similar years with no or little growth have been detected in other dwarf shrubs, for example, in Salix arctica by Polunin (1955). Buchwal et al.

170 (2013) assumed such mechanisms might be related to carbon allocation and could be irregular along the stem because growth is not homogenously allocated within the different plant segments. In accordance with their findings for Salix polaris, the specimens might preferentially allocate resources to less exposed parts (e.g., roots) in these years. In general, such partial dormancy (Preece et al., 2012) might reflect insufficient resources for the homogenous growth of the entire plant. We calculated non-growing seasons for these years, and the analyses proceeded separately, excluding them from most of our calculations.

\subsection{Environmental data collection and growth conditions}

To identify the thermal constraints of our species at the critical location, we measured soil temperatures $\left({ }^{\circ} \mathrm{C}\right)$ at a depth of 15 $\mathrm{cm}$ below the ground surface within the root zone (hereafter " $\mathrm{T}_{\mathrm{RZ}}$ ") and the air temperatures at a location $15 \mathrm{~cm}$ above the ground surface, which was within the shoot zone (hereafter " $\mathrm{T}_{\mathrm{Sz}}$ "), at all sites. Temperatures were measured at $1 \mathrm{~min}$ intervals and recorded as hourly means using ONSET's HOBO loggers (type H21-002) and type S-TMB-002 temperature sensors $\left( \pm 0.2{ }^{\circ} \mathrm{C}\right.$ accuracy). For the $\mathrm{T}_{\mathrm{SZ}}$ measurements, the sensors were equipped with passively ventilated radiation shields. Moreover, to identify the soil moisture constraints in the root zone of our specimens, we measured the volumetric soil water content $\left(\mathrm{m}^{3} / \mathrm{m}^{3}\right) 15 \mathrm{~cm}$ below the soil surface (hereafter $\mathrm{SM}_{\mathrm{RZ}}$ ) at all sites. The uncalibrated $\mathrm{SM}_{\mathrm{RZ}}$ was measured at $1 \mathrm{~min}$ intervals and recorded as hourly means using type S-SMD-M005 soil moisture sensors ( $\pm 3 \%$ accuracy). Additionally, we 
https://doi.org/10.5194/bg-2021-99

Preprint. Discussion started: 10 May 2021

(c) Author(s) 2021. CC BY 4.0 License.

(c) (i)

measured the shoot zone global radiation $\left(\mathrm{W} / \mathrm{m}^{2}\right)$ at $1 \mathrm{~cm}$ above the ground surface (hereafter $\mathrm{GR}_{\mathrm{Sz}}$ ) using a type S-LIBM003 silicon pyranometer ( $\pm 10 \mathrm{~W} / \mathrm{m}^{2}$ accuracy). Our data covered a period of 4 full calendar years from January 1, 2015, to December 31, 2018. Missing data did not occur at the chosen sites. The different near-surface regimes of $\mathrm{T}_{\mathrm{RZ}}, \mathrm{T}_{\mathrm{SZ}}, \mathrm{SM}_{\mathrm{RZ}}$, and $\mathrm{GR}_{\mathrm{SZ}}$ at our micro-topographical sites are illustrated in Fig. 1. From these raw data, we calculated a set of variables defining the micro-environmental conditions for each specimen based on the expected effects of different growth mechanisms. Averaged values for all sites $(\mathrm{N}=12)$ are summarized in Table 1.

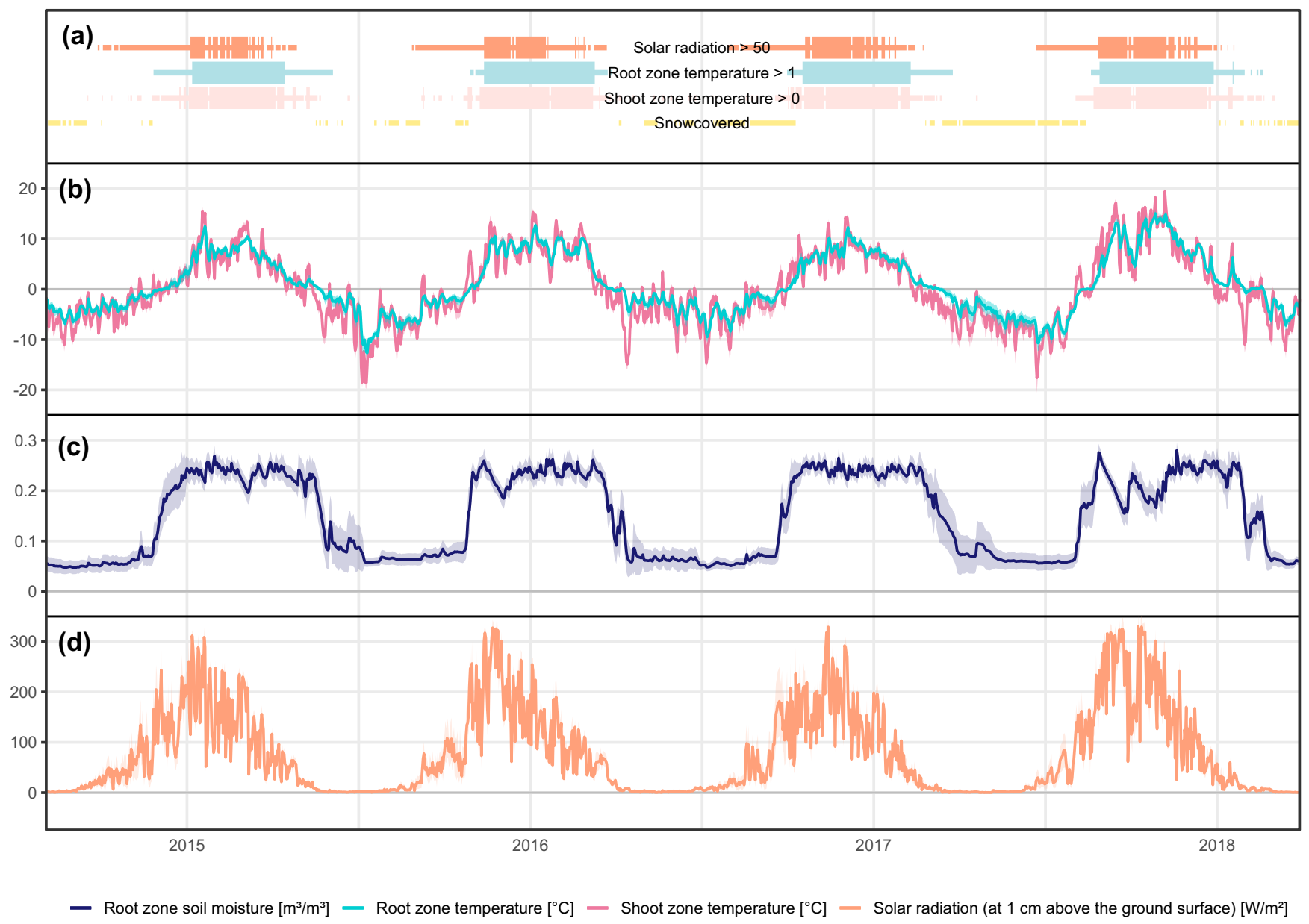

Figure 1: Micro-environmental data. Daily mean values of shoot and root zone temperatures (b), soil moisture (c), and global radiation (d). Measurements were taken at each site individually and averaged over all sites. Shaded areas indicate standard deviations. Bars (a) show time spans for certain environmental conditions, with narrow bars marking the time at which the given condition was present at least at one of the monitored sites, whereas broad bars mark the time for which the given condition was detected at all sites. 
https://doi.org/10.5194/bg-2021-99

Preprint. Discussion started: 10 May 2021

(c) Author(s) 2021. CC BY 4.0 License.

Table 1: Summary of collected environmental data. Numbers in parentheses represent inter -stem variability (standard deviation, $200+/-$ SE).

\begin{tabular}{|c|c|c|c|c|c|c|c|c|}
\hline $\begin{array}{l}\text { Environmental } \\
\text { parameter }\end{array}$ & Year & Mean & Min & $\operatorname{Max}$ & $\begin{array}{l}\text { Mean } \\
\text { spring }\end{array}$ & $\begin{array}{l}\text { Mean } \\
\text { summer }\end{array}$ & $\begin{array}{l}\text { Mean } \\
\text { autumn }\end{array}$ & $\begin{array}{l}\text { Mean } \\
\text { winter }\end{array}$ \\
\hline \multirow{8}{*}{$\begin{array}{l}\text { Shoot zone } \\
\text { temperature }\left[{ }^{\circ} \mathrm{C}\right]\end{array}$} & 2015 & 0.10 & -13.66 & 21.24 & -2.44 & 6.95 & 1.29 & -5.50 \\
\hline & & $(0.34)$ & $(0.70)$ & $(0.59)$ & $(0.34)$ & $(0.36)$ & $(0.37)$ & $(0.43)$ \\
\hline & 2016 & 0.13 & -19.53 & 21.10 & -1.39 & 8.40 & 0.30 & -6.86 \\
\hline & & $(0.30)$ & $(0.74)$ & $(0.46)$ & $(0.33)$ & $(0.33)$ & $(0.30)$ & $(0.34)$ \\
\hline & 2017 & 0.04 & -15.70 & 21.97 & -1.68 & 7.28 & -0.07 & -5.48 \\
\hline & & $(0.37)$ & $(0.40)$ & $(0.40)$ & $(0.35)$ & $(0.34)$ & $(0.45)$ & $(0.48)$ \\
\hline & 2018 & 0.55 & -19.373 & 25.156 & -1.071 & 10.029 & 0.214 & -7.782 \\
\hline & & $(0.28)$ & (1.19) & $(0.42)$ & $(0.28)$ & $(0.33)$ & $(0.32)$ & $(0.51)$ \\
\hline \multirow{8}{*}{$\begin{array}{l}\text { Root zone } \\
\text { temperature }\left[{ }^{\circ} \mathrm{C}\right]\end{array}$} & 2015 & 0.98 & -7.01 & 14.27 & -1.80 & 7.04 & 2.48 & -3.88 \\
\hline & & $(0.33)$ & $(0.56)$ & $(0.33)$ & $(0.31)$ & $(0.39)$ & $(0.32)$ & $(0.37)$ \\
\hline & 2016 & 0.96 & -13.16 & 14.37 & -1.48 & 8.76 & 2.03 & -5.52 \\
\hline & & $(0.29)$ & $(0.58)$ & $(0.42)$ & $(0.31)$ & $(0.34)$ & $(0.24)$ & $(0.36)$ \\
\hline & 2017 & 0.93 & -9.76 & 13.57 & -1.67 & 7.71 & 1.87 & -4.30 \\
\hline & & $(0.32)$ & $(0.52)$ & $(0.43)$ & $(0.28)$ & $(0.31)$ & $(0.32)$ & $(0.49)$ \\
\hline & 2018 & 1.31 & -11.03 & 16.79 & -1.76 & 10.45 & 1.67 & -5.27 \\
\hline & & $(0.25)$ & $(0.65)$ & $(0.48)$ & $(0.25)$ & $(0.34)$ & $(0.23)$ & $(0.47)$ \\
\hline \multirow{8}{*}{$\begin{array}{l}\text { Soil moisture } \\
{\left[\mathrm{m}^{3} / \mathrm{m}^{3}\right]}\end{array}$} & 2015 & 0.15 & 0.05 & 0.28 & 0.09 & 0.23 & 0.15 & 0.06 \\
\hline & & $(0.01)$ & $(0.01)$ & $(0.02)$ & $(0.03)$ & $(0.04)$ & $(0.17)$ & $(0.05)$ \\
\hline & 2016 & 0.14 & 0.06 & 0.27 & 0.12 & 0.23 & 0.12 & 0.06 \\
\hline & & $(0.01)$ & $(0.01)$ & $(0.02)$ & $(0.03)$ & $(0.04)$ & $(0.15)$ & $(0.03)$ \\
\hline & 2017 & 0.15 & 0.05 & 0.27 & 0.10 & 0.24 & 0.14 & 0.07 \\
\hline & & $(0.01)$ & $(0.01)$ & $(0.01)$ & $(0.02)$ & $(0.03)$ & $(0.15)$ & $(0.05)$ \\
\hline & 2018 & 0.15 & 0.05 & 0.312 & 0.13 & 0.21 & 0.14 & 0.06 \\
\hline & & $(0.01)$ & $(0.00)$ & $(0.01)$ & $(0.03)$ & $(0.04)$ & $(0.15)$ & $(0.03)$ \\
\hline \multirow{8}{*}{$\begin{array}{l}\text { Global radiation } \\
{\left[\mathrm{W} / \mathrm{m}^{2}\right]}\end{array}$} & 2015 & 73.11 & 0 & 809.34 & 74.38 & 169.70 & 41.82 & 4.72 \\
\hline & & $(3.90)$ & & $(24.50)$ & (11.49) & $(4.32)$ & $(1.85)$ & (1.10) \\
\hline & 2016 & 75.80 & 0 & 823.93 & 93.94 & 165.04 & 39.51 & 3.53 \\
\hline & & (3.10) & & (28.48) & $(9.32)$ & $(5.49)$ & $(2.70)$ & $(0.78)$ \\
\hline & 2017 & 70.86 & 0 & 791.81 & 78.45 & 166.59 & 32.27 & 4.26 \\
\hline & & (4.34) & & $(37.21)$ & (12.55) & (5.38) & $(1.30)$ & $(0.94)$ \\
\hline & 2018 & 85.57 & 0 & 846.38 & 117.15 & 190.84 & 28.59 & 3.25 \\
\hline & & $(3.60)$ & & $(46.05)$ & $(7.73)$ & $(7.12)$ & (1.93) & $(0.80)$ \\
\hline
\end{tabular}


https://doi.org/10.5194/bg-2021-99

Preprint. Discussion started: 10 May 2021

(C) Author(s) 2021. CC BY 4.0 License.

(c) (i)

In all four observed years, our sampled specimens experienced the highest temperatures during summer (June to September), with a slightly earlier temperature rise in 2018, beginning in May. Maximum temperatures were reached from July to September (Fig. 2). In 2018, the highest mean temperatures were expressed because of exceptionally high summer 205 temperatures (GDD10 = 57), whereas 2015 and 2017 both experienced shorter periods of high temperatures. Temperatures varied slightly among sites (Table 1), and as expected, the shoot and root zone temperature curves were well coupled. Additionally, we detected slight variability between the two studied regions, but overall similar seasonal temperature patterns on the measured micro-scale (Fig. 2), which differs from the regional climate signal described above. Global radiation showed similar patterns at all sites as well, following the course of the astronomic sun angle, with a mid-summer 210 maximum; however, there were large variations according to cloud coverage. As such, 2018 experienced a short period of temperature and radiation decrease during summer (Fig. 1).

We did not explicitly measure data regarding snow cover, but calculated snow cover from the daily shoot zone temperature amplitude and validated those calculations using radiation sensor measurements. We assumed that a daily amplitude of less

215 than $5 \%$ of the maximum amplitude reached throughout the year indicated that a layer of snow restricted daily air temperature fluctuations at the measured height of $15 \mathrm{~cm}$. The respective periods were therefore defined as snow -covered. The period in which our specimens were snow-covered varied considerably between the monitored winters and between sites. The winter of 2015/2016 had comparatively little snow, whereas 2017/2018 was snow-covered for the longest period. However, because of the chosen ridge positions, most of our monitored sites did not experience long periods of snow cover.

220 Nonetheless, snow and its presumed effects, such as mitigating extreme negative temperatures by acting as an isolating barrier and reducing the effects of frost (Körner, 2003; Bienau et al., 2014) might play a role in influencing the growth response and was therefore included in our analysis. 
https://doi.org/10.5194/bg-2021-99

Preprint. Discussion started: 10 May 2021

(c) Author(s) 2021. CC BY 4.0 License.

(c) (i)

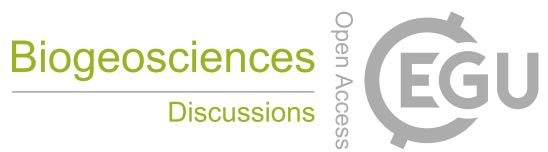

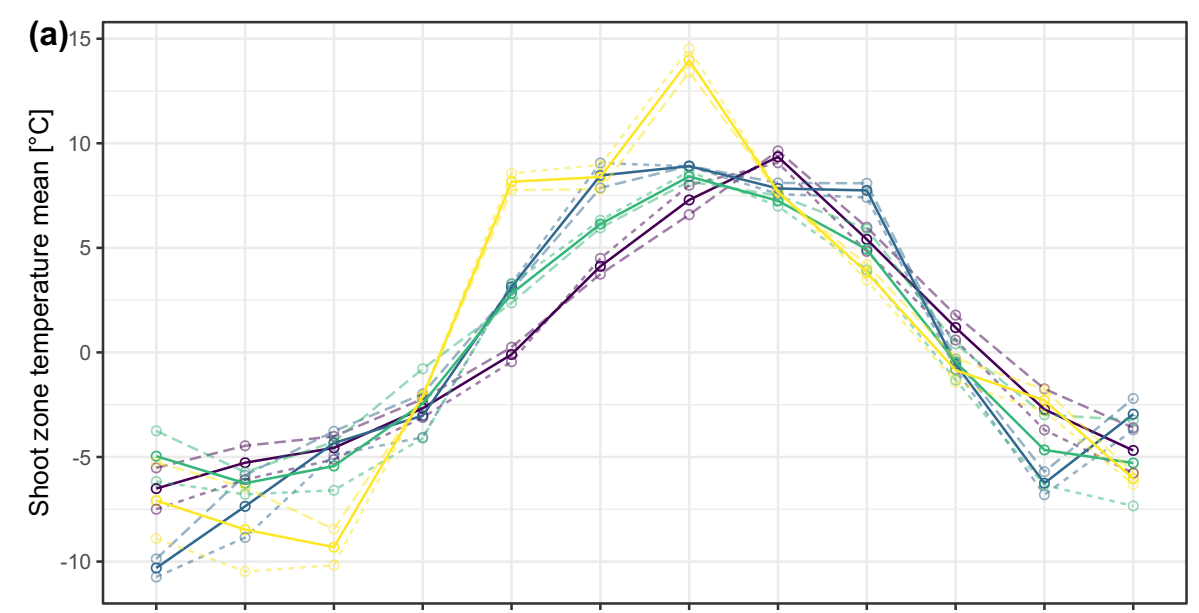

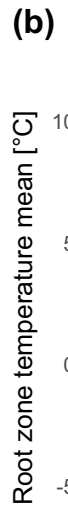

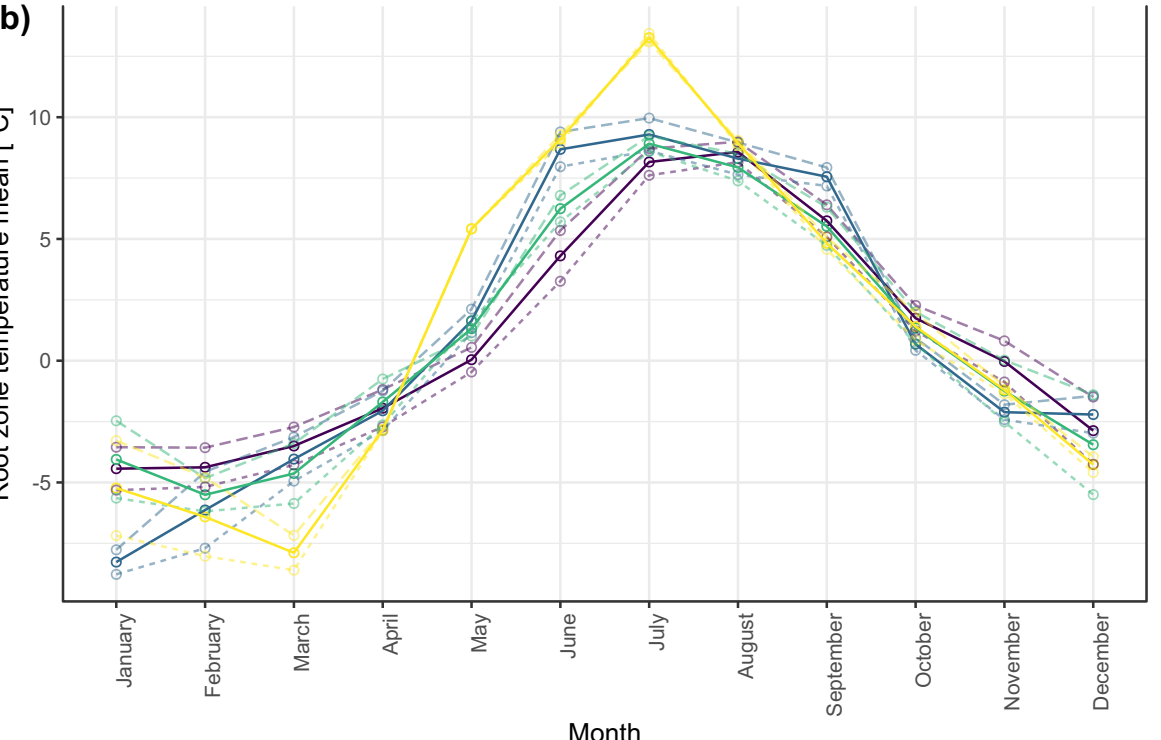

- All sites $(\mathrm{N}=12)$

- - - Geiranger/Møre og Romsdal region (West, $N=6$ )

- - Vågåmo/Oppland region (East, $\mathrm{N}=6$ )

2015

$\rightarrow 2016$

$-2017$

2018

Figure 2: Mean monthly shoot (a) and root (b) zone temperatures from 2015 to 2018 , averaged over the measured sites within the two study regions, as well as overall measured sites.

\subsection{Potential micro-environmental drivers of seasonal growth patterns}

To relate the collected data and analyze the influence of the micro-environmental conditions on the observed growth patterns, we performed a set of multiple and partial regressions and correlation analyses, calculating partial $\mathrm{R}$ squared and Pearson's correlation coefficients. Regressions were performed in R (R Development Core Team, 2020) and tested for multicollinearity among the independent variables that would have affected the regression outcome using several measures of collinearity, which are implemented in the mctest package (Imdad and Aslam, 2018). This included the determinant of the correlation matrix (Cooley and Lohnes, 1971), Farrar test of chi-square for presence of multicollinearity (Farrar and Glauber, 
https://doi.org/10.5194/bg-2021-99

Preprint. Discussion started: 10 May 2021

(c) Author(s) 2021. CC BY 4.0 License.

(c) (i)

1967), Red indicator (Kovàcs et al., 2005), Sum of lambda inverse (Chatterjee and Price, 1977) values, Theil's indicator

(Theil, 1971), and condition number (Belsley et al., 1980). A regression model was discarded if more than two of the six calculated measures indicated collinearity among the independent variables.

After testing our chosen growth parameters and their relationship to total annual growth by performing a partial regression analysis (Table 2), we analyzed the environment-growth relationship by correlating the growth parameters (total annual growth, growth initiation, peak growth, growth cessation, start of the shrinking period, peak shrinking, and day of year (DOY) at which peak shrinking occurred) with the potential micro-environmental drivers listed in Table 3, using Pearson's correlation coefficient. For each group of potential drivers (means, maxima, days at which the maxima were reached for shoot and root zone temperatures, global radiation, and soil moisture), we performed a multiple regression analysis, predicting each of the growth parameters from a fitted linear regression model. Additionally, we correlated our raw environmental data with the daily growth for each season, performing rolling correlations by aggregating our hourly data and calculating averages for preceding periods, ranging from days to years.

Table 2: Results of multiple partial regression analysis for total annual growth and annual peak shrinking against growth parameters.

\begin{tabular}{|c|c|c|c|c|c|c|c|c|}
\hline Variable & $\begin{array}{l}\text { Independent } \\
\text { variable }\end{array}$ & $\begin{array}{l}\text { Pearson's } \\
\text { correlation } \\
\text { coefficient }\end{array}$ & $\begin{array}{l}\text { Partial } \\
\mathbf{R}^{2}\end{array}$ & Part & Coefficient & $\begin{array}{l}\text { Standar } \\
\text { d Error }\end{array}$ & T-statistic & p-value \\
\hline \multirow[t]{4}{*}{$\begin{array}{l}\text { Total annual } \\
\text { growth }\end{array}$} & $\begin{array}{l}\text { Growth } \\
\text { initiation }\end{array}$ & -0.169 & -0.399 & -0.162 & -0.349 & 0.144 & -2.423 & 0.021 \\
\hline & $\begin{array}{l}\text { Growth } \\
\text { cessation }\end{array}$ & -0.245 & 0.448 & 0.187 & 0.428 & 0.153 & 2.793 & 0.009 \\
\hline & Peak growth & 0.909 & 0.922 & 0.890 & 25.228 & 1.900 & 13.278 & $<0.001$ \\
\hline & Total & & 0.930 & & & & & $<0.001$ \\
\hline \multirow[t]{4}{*}{$\begin{array}{l}\text { Annual peak } \\
\text { shrinking }\end{array}$} & $\begin{array}{l}\text { Growth } \\
\text { initiation }\end{array}$ & 0.133 & 0.144 & 0.129 & 0.209 & 0.259 & 0.808 & 0.425 \\
\hline & $\begin{array}{l}\text { Growth } \\
\text { cessation }\end{array}$ & 0.016 & -0.037 & -0.033 & -0.057 & 0.275 & -0.057 & 0.838 \\
\hline & Peak growth & 0.402 & 0.395 & 0.383 & 8.167 & 3.411 & 2.394 & 0.023 \\
\hline & Total & & 0.790 & & & & & $<0.001$ \\
\hline
\end{tabular}


https://doi.org/10.5194/bg-2021-99

Preprint. Discussion started: 10 May 2021

(c) Author(s) 2021. CC BY 4.0 License.

Table 3: Summary of calculated micro-environmental parameters (means). Numbers in parentheses represent inter-stem variability (standard deviation, +/- SE).

\begin{tabular}{|c|c|c|c|c|}
\hline Parameter & 2015 & 2016 & 2017 & 2018 \\
\hline \multicolumn{5}{|l|}{ Shoot zone temperature $\left(T_{s z}\right)$} \\
\hline Day, when maximum $\mathrm{T}_{\mathrm{sz}}$ is reached [DOY] & $\begin{array}{l}183 \\
(5.36)\end{array}$ & $203(7.41)$ & $\begin{array}{l}203 \\
(0.29)\end{array}$ & $\begin{array}{l}208 \\
(0)\end{array}$ \\
\hline First day, at which $\mathrm{T}_{\mathrm{sz}}>0[\mathrm{DOY}]$ & $\begin{array}{l}100 \\
(9.24)\end{array}$ & $74(7.28)$ & $\begin{array}{l}25 \\
(12.41)\end{array}$ & $\begin{array}{l}104 \\
(0.56)\end{array}$ \\
\hline Annual $\mathrm{T}_{\mathrm{sz}}$ sum $\left[{ }^{\circ} \mathrm{C}\right]$ & $\begin{array}{l}37.28 \\
(125.36)\end{array}$ & $\begin{array}{l}47.96 \\
(109.48)\end{array}$ & $\begin{array}{l}16.21 \\
(133.57)\end{array}$ & $\begin{array}{l}199.96 \\
(102.65)\end{array}$ \\
\hline Tsz sum at growth initiation $\left[{ }^{\circ} \mathrm{C}\right]$ & $\begin{array}{l}-291.87 \\
(57.03)\end{array}$ & $\begin{array}{l}-421.91 \\
(134.73)\end{array}$ & $\begin{array}{l}-189.45 \\
(96.27)\end{array}$ & $\begin{array}{l}-384.76 \\
(139.80)\end{array}$ \\
\hline Number of days with $\mathrm{T}_{\mathrm{sz}}>0$ (Growing degree days, GDD0) [days] & $\begin{array}{l}175 \\
(6.91)\end{array}$ & $169(4.48)$ & $\begin{array}{l}165 \\
(5.09)\end{array}$ & $\begin{array}{l}173 \\
(5.38)\end{array}$ \\
\hline Number of days with $\mathrm{T}_{\mathrm{sz}}>5$ (Growing degree days, GDD5) [days] & $\begin{array}{l}82 \\
(5.50)\end{array}$ & $117(3.93)$ & $\begin{array}{l}100 \\
(6.74)\end{array}$ & $\begin{array}{l}121 \\
(3.73)\end{array}$ \\
\hline Number of days with $\mathrm{T}_{\mathrm{sz}}>10$ (Growing degree days, GDD10) [days] & $\begin{array}{l}21 \\
(2.53)\end{array}$ & $32(4.57)$ & $\begin{array}{l}12 \\
(2.80)\end{array}$ & $\begin{array}{l}57 \\
(3.27)\end{array}$ \\
\hline
\end{tabular}

Root zone temperature $\left(T_{R Z}\right)$

Day, when maximum $\mathrm{T}_{\mathrm{RZ}}$ is reached [DOY]

$\begin{array}{llll}186 & 206 & 204 & 197 \\ (0.08) & (0) & (0.11) & (1.6) \\ 146 & 140(1.73) & 139 & 127 \\ (3.95) & & (1.43) & (1) \\ 358.52 & 351.23 & 339.15 & 477.58 \\ (121.54) & (104.54) & (117.34) & (90.09) \\ -127.05 & -326.05 & -116.97 & -303.43 \\ (79.27) & (140.50) & (90.72) & (149.08) \\ 182 & 170(4.19) & 176 & 196 \\ (8.01) & & (5.78) & (5.99) \\ 96 & 124 & 117 & 119 \\ (5.75) & (2.14) & (5.27) & (2.74) \\ 7 & 14 & 10 & 57 \\ (3.70) & (7.48) & (3.68) & (4.10)\end{array}$

First day, at which $\mathrm{T}_{\mathrm{RZ}}>1$ [DOY]

Annual $\mathrm{T}_{\mathrm{RZ}} \operatorname{sum}\left[{ }^{\circ} \mathrm{C}\right]$

$\mathrm{T}_{\mathrm{RZ}}$ sum at growth initiation $\left[{ }^{\circ} \mathrm{C}\right]$

Number of days with $\mathrm{T}_{\mathrm{RZ}}>0$ (Growing degree days, GDD0) [days]

(7.48)

(3.68)

(4.10)

\section{Soil moisture}

Day, when maximum soil moisture is reached [DOY]

$\begin{array}{llll}197 & 219 & 193 & 222 \\ (21.28) & (17.38) & (18.85) & (22.02) \\ 351 & 342(3.16) & 351 & 353\end{array}$

Day, when minimum soil moisture is reached in autumn [DOY] 
https://doi.org/10.5194/bg-2021-99

Preprint. Discussion started: 10 May 2021

(c) Author(s) 2021. CC BY 4.0 License.

(c) (i)

\begin{tabular}{|c|c|c|c|c|}
\hline & $(3.25)$ & & $(2.32)$ & $(2.88)$ \\
\hline \multirow[t]{2}{*}{ Annual soil moisture sum $\left[\mathrm{m}^{3} / \mathrm{m}^{3}\right]$} & 54.65 & 52.78 & 55.52 & 54.51 \\
\hline & $(4.09)$ & $(3.53)$ & $(3.46)$ & $(3.47)$ \\
\hline \multirow[t]{2}{*}{ First day, at which soil moisture $>0.15$ [DOY] } & 135 & $128(2.53)$ & 126 & 110 \\
\hline & $(3.37)$ & & $(6.51)$ & $(3.28)$ \\
\hline
\end{tabular}

\section{Global radiation}

Day, when maximum global radiation is reached [DOY]

First day, when global radiation $>50 \mathrm{~W} / \mathrm{m}^{2}$ [DOY]

Annual global radiation sum $\left[\mathrm{W} / \mathrm{m}^{2}\right]$

Global radiation sum at growth initiation $\left[\mathrm{W} / \mathrm{m}^{2}\right]$

Snow

Number of snow-free days [days]

First autumn frost $\left(\mathrm{T}_{\mathrm{RZ}}<0^{\circ} \mathrm{C}\right)[\mathrm{DOY}]$
171

(4.53)

$\begin{array}{llll}361 & 361(5.53) & 358 & 356 \\ (4.90) & & (13.79) & (9.48) \\ 320 & 296(2.84) & 310 & 301 \\ (3.60) & & (4.58) & (4.70)\end{array}$

\section{Results}

\subsection{Intra-annual growth patterns}

255 In general, the seasonal variability in the stem diameter was well explained by non-linear, sigmoid regressions (Gompertz curves) with a GoF between 0.90 and 0.94 (Fig. 3), and all specimens experienced distinct growing seasons. Moreover, our data revealed a distinct phase of stem radial contraction (shrinking) following the growing phase toward the end of the year, starting in October, with remarkably little variation in timing between years (on average from the $287^{\text {th }}$ to the $311^{\text {th }}$ Julian day). In most cases, the stem radius remained below the previously achieved maximum for the entire winter and started to

260 increase again with the following year's growing season (Fig. 3). The timing of this shrinking period was significantly linked to the day when peak growth occurred $(\mathrm{R}=0.50, \mathrm{p}=0.004)$, as well as to growth initiation $(\mathrm{R}=0.40, \mathrm{p}=0.023)$ and cessation $(\mathrm{R}=0.52, \mathrm{p}=0.0023)$. 
https://doi.org/10.5194/bg-2021-99

Preprint. Discussion started: 10 May 2021

(c) Author(s) 2021. CC BY 4.0 License.

(c) (i)
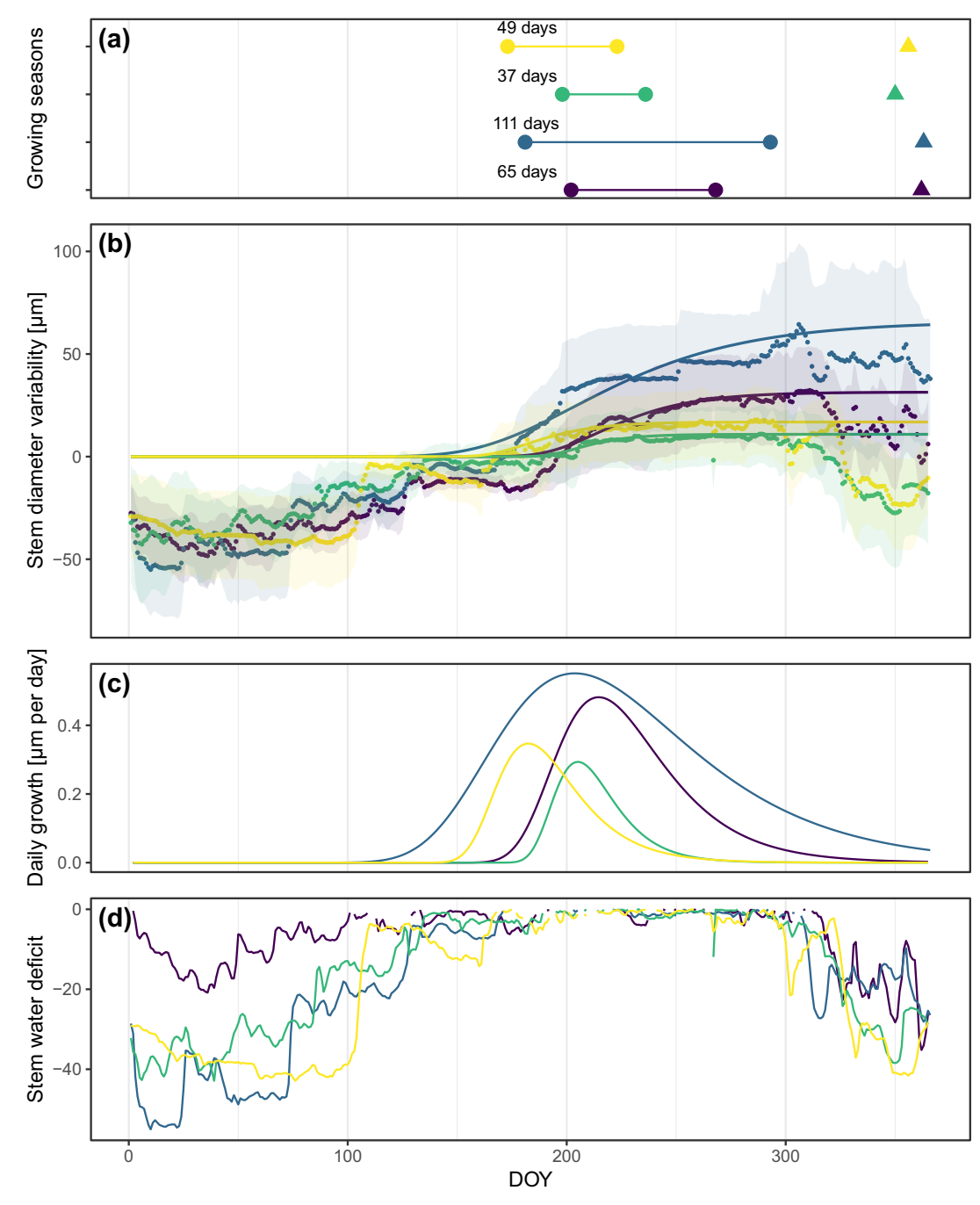

$$
\begin{aligned}
-2015, \mathrm{GoF}= & 0.943 \\
-\quad 2016, \mathrm{GoF}= & 0.902 \\
-2017, \mathrm{GoF}= & 0.915 \\
-2018, \mathrm{GoF}= & 0.911
\end{aligned}
$$

265 Figure 3: Observed and modelled variability in stem diameter. (a) Growing seasons derived from fitted Gompertz models and timing of peak shrinking defined as the minimum of the observed shrinking phase toward the end of the year (triangles). (b) Averaged measured daily stem diameter variability and Gompertz models fitted to zero growth curves. Shaded areas indicat $\mathrm{e}$ standard deviation showing the variability among the specimens. (c) Daily growth derived from Gompertz models. (d) Stem water deficit defined as reversible radial stem variability at times when no growth -induced irreversible stem expansion was measured. 
https://doi.org/10.5194/bg-2021-99

Preprint. Discussion started: 10 May 2021

(c) Author(s) 2021. CC BY 4.0 License.

Total annual growth ranged from $11 \mu \mathrm{m}$ in 2017 to $65 \mu \mathrm{m}$ in 2016, on average, with the growing season starting in May or June (Table 4 and Fig. 3). Interestingly, year-to-year variability and patterns in total growth were similar in the two studied regions (Fig. A3). Furthermore, our data showed slight differences in seasonal growth patterns between the two regions, but no clear overall patterns beyond the high inter-specimen variability observed in the whole dataset (Fig. A4). Our chosen growth parameters, growth initiation, peak growth, and growth cessation, together explained $93 \%$ of the variance in total annual growth, with peak growth having by far the greatest influence. For stem contraction (shrinking), the same parameters explained $79 \%$ of the variance (Table 2 and Fig. A5), suggesting that the observed winter shrinking in E. hermaphroditum might be linked to growth during the growing season.

280 Table 4: Growth parameters (means). Numbers in parentheses represent variability between specimens (standard dev iation, +/SE).

\begin{tabular}{lllll}
\hline \hline Year & $\mathbf{2 0 1 5}$ & $\mathbf{2 0 1 6}$ & $\mathbf{2 0 1 7}$ & $\mathbf{2 0 1 8}$ \\
\hline \hline Stem radial variability $[\mu \mathrm{m}]$ & $31.74(12.73)$ & $63.86(11.62)$ & $11.35(20.79)$ & $19.91(11.08)$ \\
Stem radial growth $[\mu \mathrm{m}]$ & $31.81(11.53)$ & $64.66(21.82)$ & $14185(6.27)$ & $17.45(9.46)$ \\
Stem radial shrinking $[\mu \mathrm{m}]$ & $35.18(10.35)$ & $28.13(14.44)$ & $38.45(12.77)$ & $41.61(13.47)$ \\
Day peak shrinking occurs $[\mathrm{DOY}]$ & $362(16.62)$ & $363(4.38)$ & $350(17.16)$ & $356(13.63)$ \\
Day shrinking starts $[\mathrm{DOY}]$ & $311(26.38)$ & $306(14.07)$ & $289(10.35)$ & $287(12.81)$ \\
Growth initiation $[\mathrm{DOY}]$ & $202(12.56)$ & $181(12.12)$ & $198(8.49)$ & $173(13.65)$ \\
Growth cessation $[\mathrm{DOY}]$ & $267(14.06)$ & $292(14.87)$ & $235(12.24)$ & $222(15.47)$ \\
Growth duration $[$ days] & $65(7.93)$ & $111(7.14)$ & $37(10.70)$ & $49(9.04)$ \\
Peak growth $[\mu \mathrm{m}]$ & $0.48(0.40)$ & $0.55(0.85)$ & $0.29(0.20)$ & $0.35(0.50)$ \\
Day peak growth occurs $[\mathrm{DOY}]$ & $215(13.68)$ & $204(9.54)$ & $205(8.24)$ & $182(13.85)$ \\
Mean daily growth $[\mu \mathrm{m}]$ & $0.09(0.03)$ & $0.18(0.06)$ & $0.03(0.02)$ & $0.05(0.03)$ \\
\hline
\end{tabular}

\subsection{Micro-environmental drivers of growth patterns}

We investigated how the specific micro-environmental conditions were correlated with the growth parameters described 285 above using a set of potential micro-environmental drivers for each site. Together, all 25 chosen micro-environmental parameters (Table 3) were able to explain the total annual growth to a very large extent. Separate regression models for each micro-environmental variable revealed an overall high explanatory power for global radiation and soil moisture, on total annual growth and peak growth, compared to temperatures (Fig. 4). However, correlating temporarily aggregated data 
https://doi.org/10.5194/bg-2021-99

Preprint. Discussion started: 10 May 2021

(c) Author(s) 2021. CC BY 4.0 License.

(c) (i)

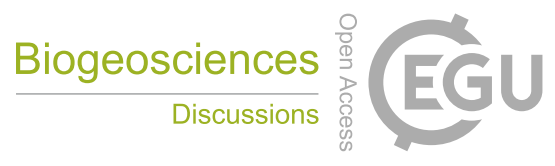

revealed that all measured environmental parameters influenced stem radial variation, but at different time scales, with radiation taking a longer time to show effects on stem increment. Comparisons of seasons also showed that microenvironmental influences had strong explanatory power during spring when the plants experienced their main growing phase. Conversely, the explanatory power was comparatively low during autumn, when stem shrinking was detected (Fig. 5).

The correlations with our micro-environmental parameters (Fig. 6) indicated that a multitude of micro-environmental drivers influenced growth, yet, to a very low degree and with high inter-annual variation. Maximum soil moisture was significantly correlated with total annual growth $(\mathrm{R}=0.47)$. Minimum soil moisture was positively correlated with growth cessation $(\mathrm{R}=$ $0.56)$, as were annual mean soil moisture $(\mathrm{R}=0.40)$ and the sum $(\mathrm{R}=0.39)$, indicating a strong overall influence of soil moisture on growth processes throughout all four seasons. Growth initiation, on the other hand, was linked to spring radiation $(R=-0.37)$ and winter temperatures $(R=0.40)$. Furthermore, growth cessation was negatively correlated with maximum shoot zone temperatures $(\mathrm{R}=-0.46)$, mean summer temperatures $(\mathrm{R}=-0.40)$, and GDD5 $(\mathrm{R}=-0.40)$. This result suggested that high peak temperatures during the summer might delay growth cessation by the thermal promotion of carbohydrate storage, enabling growth continuity even under unfavorable thermal constraints during autumn (Fig. 6). 
https://doi.org/10.5194/bg-2021-99

Preprint. Discussion started: 10 May 2021

(c) Author(s) 2021. CC BY 4.0 License.

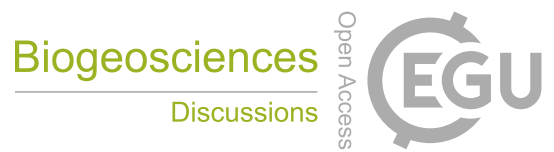

(c) (1)
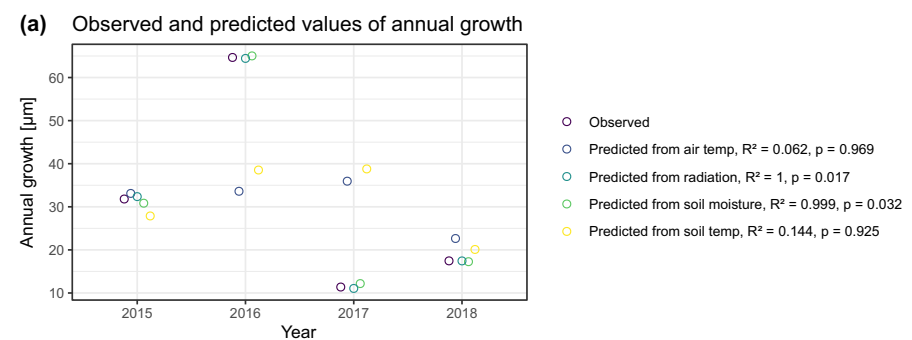

(b) Observed and predicted values of growth initiation

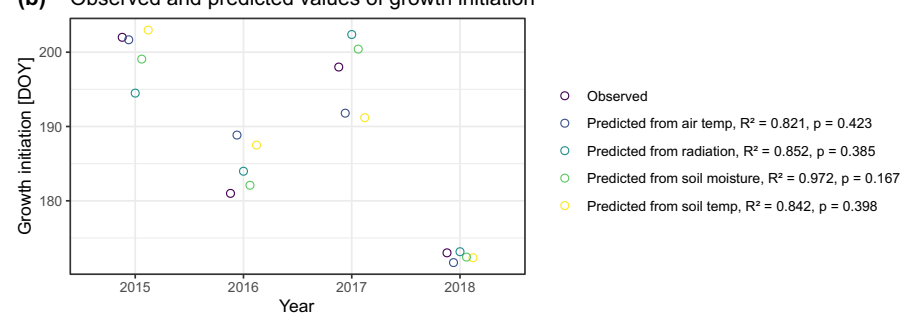

(c) Observed and predicted values of growth cessation

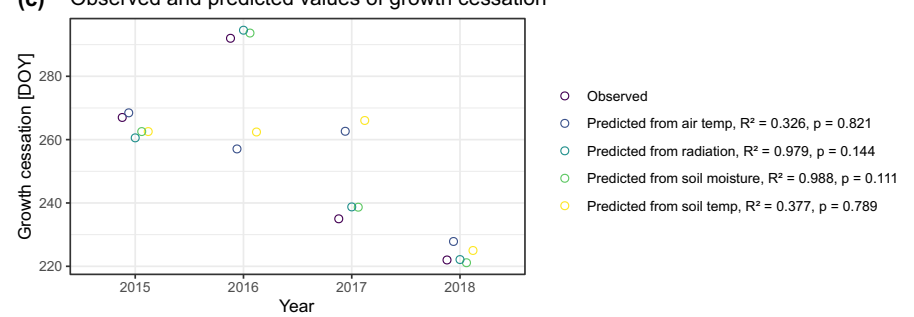

(d) Observed and predicted values of peak growth

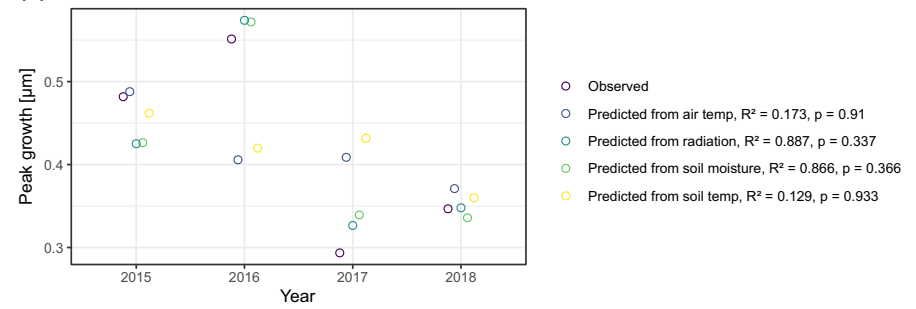

(e) Observed and predicted values of peak shrinking

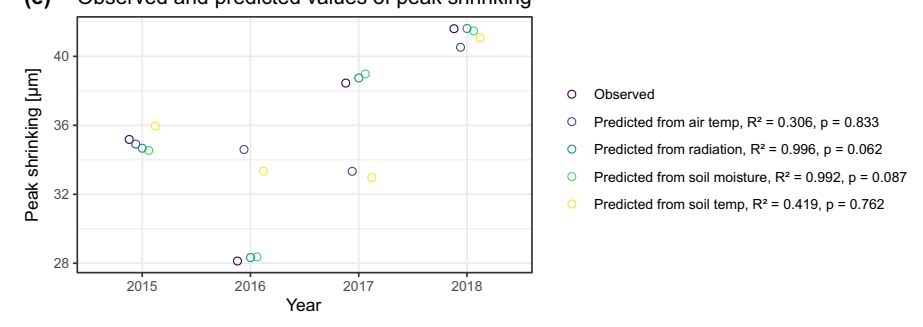

305 Figure 4: Observed and predicted values of micro-environmental growth drivers (total annual growth, growth initiation, peak growth, growth cessation, and peak shrinking). Predictions were obtained from mean and Julian day at which the maximum occurred for four micro-environmental drivers. 
https://doi.org/10.5194/bg-2021-99

Preprint. Discussion started: 10 May 2021

(c) Author(s) 2021. CC BY 4.0 License.

(a) Correlation with mean values

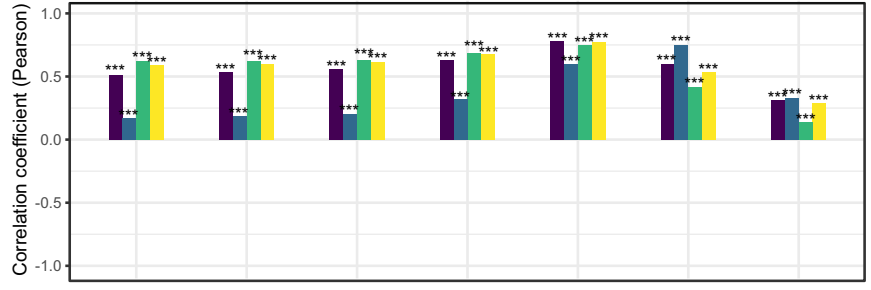

(b) Correlation with mean values (Winter)

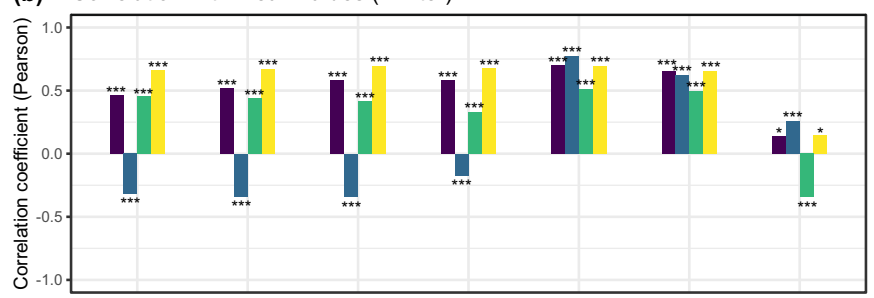

(c) Correlation with mean values (Spring)

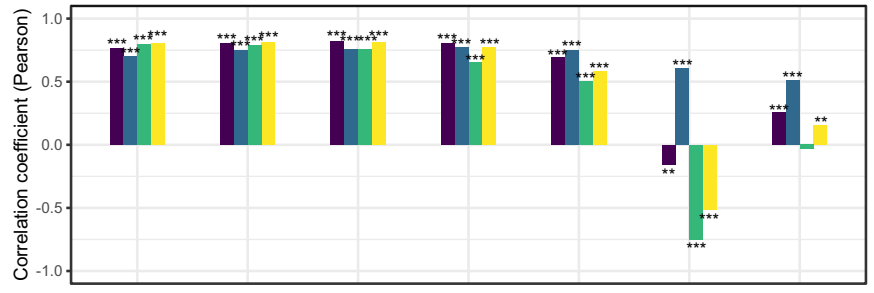

(d) Correlation with mean values (Summer)

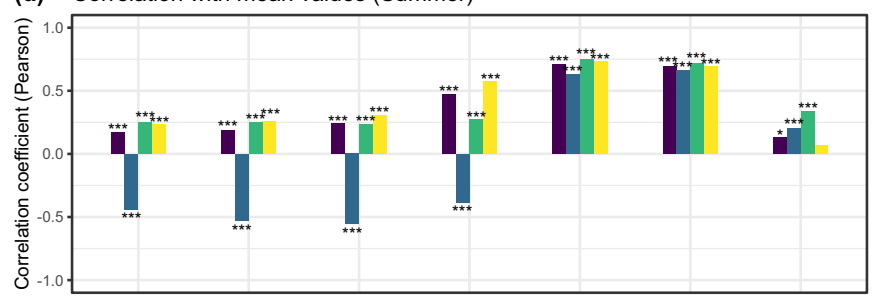

(e) Correlation with mean values (Autumn)

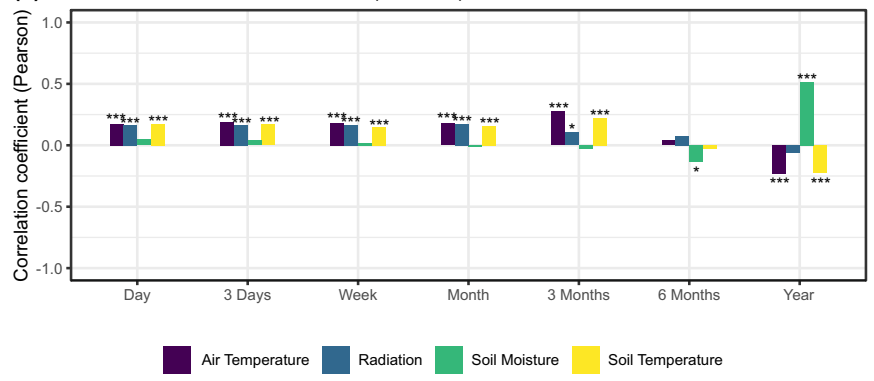

310 Figure 5: Pearson correlation coefficients for radial stem diameter against aggregated microenvironmental data (shoot and roo t zone temperatures, soil moisture, and global radiation). Each daily value of stem variability was correlated with the environmental mean of the prior period of up to one year. All 12 monitored specimens entered into the correlation analysis with individual values for both stem diameter and microenvironmental parameters. 
https://doi.org/10.5194/bg-2021-99

Preprint. Discussion started: 10 May 2021

(c) Author(s) 2021. CC BY 4.0 License.

(c)
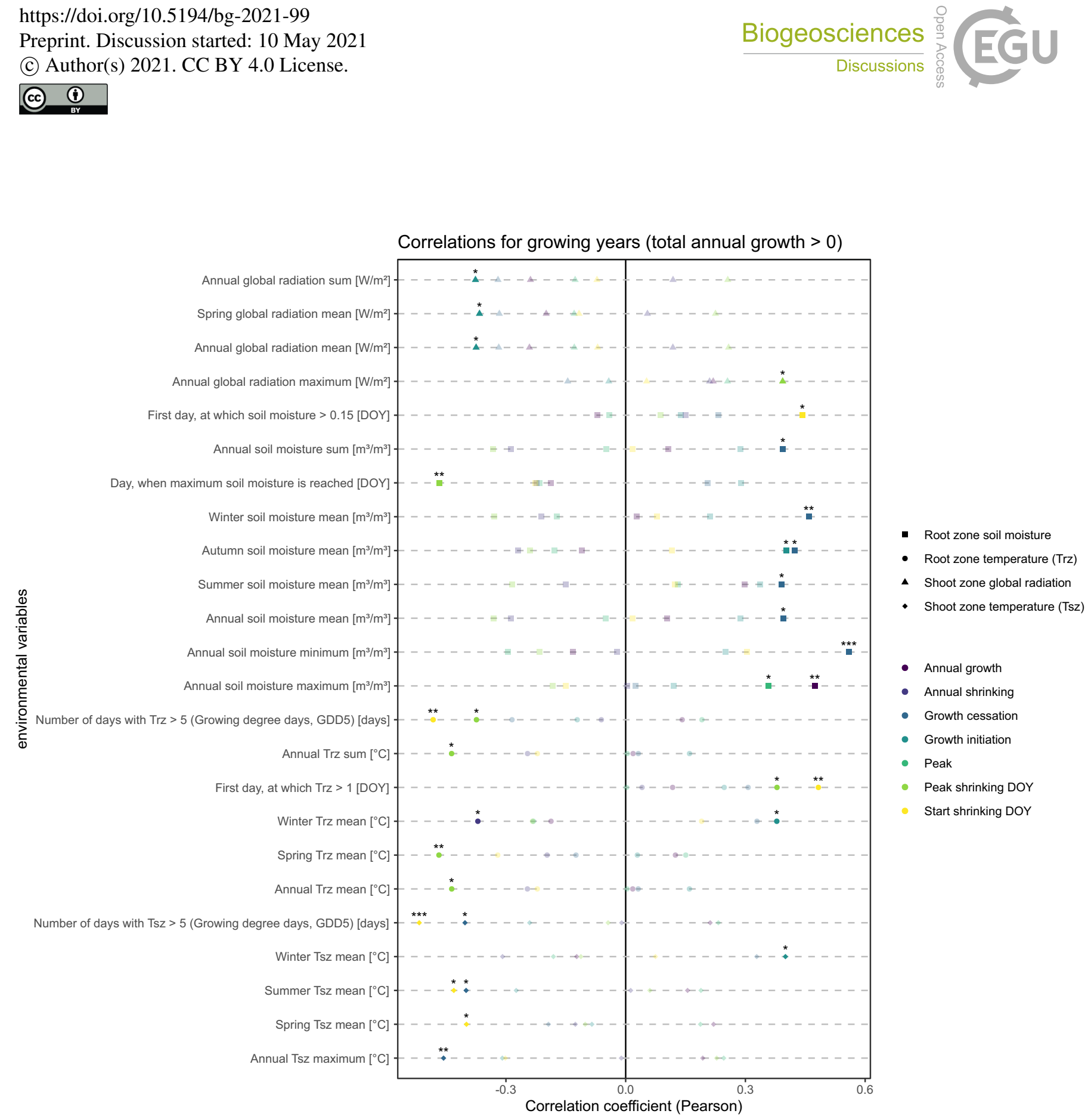

Figure 6: Pearson's correlation coefficients for growth -defining parameters with parameters defining micro-environmental conditions (in years with total annual growth $>0$ ). Only environmental parameters, which correlated significantly with at lea st one growth parameter, are included in the plot. Darker shades indicate significance $(* * *=\mathbf{p}$-value $<0.001, * *=\mathbf{p}$-value $<0.01, *=\mathbf{p}$ value $<0.05)$. 
https://doi.org/10.5194/bg-2021-99

Preprint. Discussion started: 10 May 2021

(c) Author(s) 2021. CC BY 4.0 License.

(c) (i)

\section{Discussion}

\subsection{Intra-annual growth patterns}

In this study, we demonstrated that our focus species Empetrum hermaphroditum displayed distinct annual growth patterns in response to near-ground environmental drivers and in close accordance with distinct conditions caused by local topography. These unique micro-environmental characteristics of the studied ridge positions are a feature of the heterogenous topography that characterizes alpine terrain (Scherrer and Körner, 2011). They include high exposure to global radiation and very little snow cover during the winter months, associated with very low temperatures (Wundram et al., 2010), as well as a layer of lichens, keeping soil moisture and reducing the danger of summer drought (Löffler, 2005). These conditions varied comparatively little between the study regions (Fig. 2), and lead to very similar seasonal growth patterns

330 (Fig. A4), suggesting that their influence on growth conditions was stronger than prominent regional environmental signals, which were not reflected in our growth data, as suggested by Bär et al. (2008).

Thus, we confirm findings by Bienau et al., (2014), suggesting that E. hermaphroditum had consistent response patterns to micro-environmental drivers and our results endorse the crucial role of topography in determining growth response (Ropars et al., 2015). In contrast to the oceanic-continental gradient, our study showed high intra-plant growth variability (Fig. A1 and Fig. A3), which has been previously described in E. hermaphroditum (Bär et al., 2008) and could be a result of the nanoscale of internal growth variability within the multi-stemmed plant itself (Bär et al., 2007).

Our findings regarding seasonally differentiated response to near ground environmental conditions (Fig. 5) highlight the importance of winter conditions for early growth. This indicates that for our sampled evergreen species at the chosen sites, which experienced only short periods of snow cover that otherwise would be likely to influence the growth response, the degree to which photosynthetic activity was energetically effective in synthesizing carbohydrates during the winter months was especially important. Such continued activity was found in E. hermaphroditum, as well as several other evergreen shrub species before (e.g. Bienau et al., 2014; Wyka and Oleksyn, 2014; Blok et al., 2015). Long and severe ground frosts might

345 limit access to soil moisture, and frost-triggered droughts might result in tissue damage caused by an internal water deficit. At the same time low temperatures prevented cell production and differentiation, resulting in a carbon overflow (Körner, 2015; Saccone et al., 2017), which gives E. hermaphroditum the ability to reduce wintertime losses of carbon (Starr and Oberbauer, 2003), start growth activity as soon as liquid water is available in the root zone, and acquire nitrogen early in the season. This ability to use additional photosynthetic opportunities throughout the year is similar to mechanisms found in

350 Juniper thurifera (Gimeno et al., 2012). Global radiation plays a major role here because light can promote photosynthesis, while nutrient uptake is severely restricted (Saccone et al., 2017). Accordingly, we identified winter and spring radiation a s a strong driver, which caused the start of the growth phase (Fig. 5). The ability to preserve resources produced during the 
https://doi.org/10.5194/bg-2021-99

Preprint. Discussion started: 10 May 2021

(c) Author(s) 2021. CC BY 4.0 License.

\section{(c) (i)}

winter months would give E. hermaphroditum a local advantage compared to broadleaved species at the same sites. However, it remains unclear, if these assumptions hold true at other micro-topographic positions, where energy budget and water balance is strongly altered (Dahl, 1956; Fritts, 1976; Löffler et al., 2006; Pape et al., 2009).

\subsection{Total annual growth}

Our results showed that total annual growth was largely determined by peak growth, indicating that the overall duration of the growth phase was less important for overall growth than the daily growth rate. Thus, total annual growth can be interpreted as a function of daily growth. Comparing the environmental drivers, annual growth can be best predicted by soil moisture and, to some extent, by global radiation, whereas shoot and root temperatures have minor explanatory power. In inter-annual comparison, this was especially evident in 2018, the year experiencing the highest temperatures. Despite these conditions, the average total growth was considerably lower than in 2016 (17 $\mu \mathrm{m}$ compared to $65 \mu \mathrm{m})$. A possible explanation might lie within the spring conditions (March, April, and May) (Fig. 4). In 2018, temperatures rose to comparatively high values in April and early May (Fig. 2), with soil temperatures above $0{ }^{\circ} \mathrm{C}$ and consequent thawing processes evident in our soil moisture data. This early warm phase was followed by a short cold snap and ground frost. This would explain the early growth start in 2018 , and the absence of high growth rates despite favorable summer conditions, indicating that an early growth start may not be efficient in terms of total growth, if conditions in early summer prevent the survival of the formed cells. For most snow-free ridges, budburst and flowering are not influenced by snowmelt and can, therefore, occur early on, causing high vulnerability to late frost events (Weijers et al., 2018a). This is in accordance with the findings of Choler (2018) and Weijers et al. (2018b), who suggested the strong influence of freezing temperatures in spring, counteracting improved conditions during summer. Here, it is worth noting that the contrasting year, 2016, experienced the highest number of days with soil temperatures above $5{ }^{\circ} \mathrm{C}$ and temperatures rose quickly and steadily to that threshold without reaching continuously higher values during the summer (Fig. 1). This could indicate that optimum growth conditions lie within a soil temperature span of 5 to $10{ }^{\circ} \mathrm{C}$, which is in accordance with previously reported temperature thresholds for alpine plant distribution (Körner and Paulsen, 2004; Rossi et al., 2008; Steppe et al., 2015). On the other hand, our regression analysis indicated no direct relationship between total growth and near-surface temperatures and no clear thermal growth limit, suggesting more complex connections, probably influenced by the evident temperature extremes at our chosen sites (Körner and Hiltbrunner, 2018). Thus, in our studied alpine environment, we cannot confirm high temperatures as the main general driver of shrub growth, as was assumed in several previous studies (i.e., Elmendorf et al., 2012; Hollesen et al., 2015; Ackerman et al., 2017; Weijers et al., 2018b).

Overall, we found high variability in annual growth between specimens and years, with some specimens experiencing zero growth in more than one year. This occurred in $31 \%$ of the dendrometer curves, mostly in 2017 (15\%). We therefore attributed these dormant years to comparatively long periods of snow cover during the previous winter, which might have 
https://doi.org/10.5194/bg-2021-99

Preprint. Discussion started: 10 May 2021

(c) Author(s) 2021. CC BY 4.0 License.

(c) (i)

prevented E. hermaphroditum from the photosynthetic activity and resource accumulation, and thus, may have limited a crucial precondition of growth success. This assumption was supported by a highly negative correlation between stem diameter variation and the number of snow-free days $(R=-0.60, p=0.024$, Fig. A6) during these years. The effects of winter snow cover on shrub growth are a critical topic in arctic and alpine ecology, with findings ranging from positive (Blok et al., 2015; Addis and Bret-Harte, 2019) to negative (Schmidt et al., 2010) growth responses, depending on snow depth and vegetation type. In accordance with Buchwal et al., (2013), we assumed that during years of no apparent radial growth, dwarf shrubs might invest in root growth instead of shoot growth to prepare for the following winter. This ability to reduce cambial activity to a minimum and cease above-ground wood formation is a trait common among woody plants (Wilmking et al., 2012). However, this implies that our studied specimens were locally adapted to snow-free conditions at their exposed positions, and consequently, might not be able to cope with such unexpected growth conditions.

\subsection{Peak growth}

We found peak growth, the maximum daily growth rate, was closely linked to soil moisture and usually occurred in connection with the soil moisture maximum, highlighting the overall importance of the root zone soil moisture as the key driver of growth in E. hermaphroditum (Fig. 6). This was evident in the strong contraction and expansion patterns of the stems, most likely controlled by active or passive water level variability within the plant, linked to the extreme thawing and freezing processes prominent at our study sites. The predominant role of peak growth in controlling total growth suggested that the shrubs were usually able to invest in new cells following the cell water level rise caused by thawing conditions, most likely affected by prior carbohydrate storage (see above).

In trees, the timing of maximum growth in cold environments has been linked to day length (Rossi et al., 2006; Duchesne et al., 2012). This cannot be confirmed for our monitored shrubs because of the high variability between specimens, showing a far broader range in the Julian day at which peak growth occurred than observed in trees. Therefore, peak growth is most likely controlled by other factors in shrubs than those assumed for trees, where available soil moisture is not limiting during the photosynthetically active period in spring and early summer. Instead, our results suggest that soil moisture availability played a key role.

\subsection{Growth initiation and cessation}

We found the overall link of growth initiation and cessation to the micro-environment comparably low, indicating that growth duration was most likely influenced by a multitude of environmental variables with large differences between years and sites (Fig. 4 and Fig. 6). From the positive correlation of growth initiation with global radiation during spring we concluded that growth initiation might be driven by the constantly increasing radiation with the astronomic rise of the angle 415 of the sun. At this time of the year, energy transfer from global radiation into thermal heat was low, but radiation was high 
https://doi.org/10.5194/bg-2021-99

Preprint. Discussion started: 10 May 2021

(c) Author(s) 2021. CC BY 4.0 License.

(c) (i)

(1)

enough for photosynthetic activity, which might explain the decoupling of thermal and radiation drivers of growth initiation. Furthermore, growth initiation in E. hermaphroditum was positively linked to winter temperatures in our study (Fig. 6), indicating that low winter temperatures were correlated with an early start of the growing season, in contrast to common assumptions relating high late winter temperatures to an early growth start (Dolezal et al., 2020). This highlights the influence of high radiation on energy storage during periods of an absent snow cover, which is usually accompanied by low temperatures, whereas mild winters are often associated with cloudy, humid weather, and snow cover on the ridges. For growth cessation, decreasing day length was determined an unlikely trigger (Heide, 1985), because of high inter-stem variability. Instead, shoot zone temperatures played a role in determining when xylogenesis ceased, but a critical temperature threshold, as present in many trees (Rossi et al., 2007; Rossi et al., 2008; Deslauriers et al., 2008) and found for xylem growth of alpine rhododendron shrubs ( $\mathrm{Li}$ et al., 2016), could not be determined for E. hermaphroditum. Instead, we identified soil moisture as the main driver for the end of the growing season.Yet, we could not determine a minimum soil moisture threshold, which would lead to growth cessation. A contrasting pattern was shown in 2016, with a prolonged growing phase after dry conditions during early summer. Thus, we concluded that E. hermaphroditum growth was strongly dependent on the availability of water, which is why dry conditions during spring and early summer were less crucial and did

430 not lead to immediate growth cessation, because evaporation was not fully active at these times of the year leaving enough exploitable moisture available. This accounts for the species dependency on a damp climate and high rainfall (Bell and Tallis, 1973). In a close relationship with the end of growth, the stem diameter started to shrink, marking the beginning of the winter shrinking period.

\subsection{Stem shrinking}

435 The phase of stem shrinking during the winter months is usually not present in trees and might, therefore, be interpreted as a unique feature of shrub growth, which we documented for the first time in this study. The reason why this mechanism has not been described earlier might be attributable to the methods for shrub growth measurements used in the past, which were insufficient to document intra-annual variability at the appropriate scale. High-precision point dendrometers can reveal these patterns in growth variability, demonstrating the large amount of additional information gained from this method compared

440 to traditional measuring methods.

In trees, radial stem shrinkage has been related to sap flow and tree water content (Zweifel et al., 2006; Tian et al., 2019). As our observed shrinking phase occurred during periods of extremely low temperatures during winter and was negatively correlated with root zone temperatures during these months, we assumed a relationship with the high subzero temperatures

445 and consequent freezing conditions present at our study sites. As such, stem shrinkage could be interpreted as a result of freezing processes causing living cell shrinkage because of water losses, as commonly observed in trees and other woody plants (Neuner, 2014; Charra-Vaskou et al., 2016). As subzero temperatures are a major environmental stress factor, alpine 
https://doi.org/10.5194/bg-2021-99

Preprint. Discussion started: 10 May 2021

(c) Author(s) 2021. CC BY 4.0 License.

(c) (i)

(1)

shrubs have developed a strategy to avoid frost damage, especially where the protective effects of snow cover are missing (Kuprian et al., 2014; Neuner, 2014). We assume that E. hermaphroditum similarly uses cell dehydration to actively protect living cells from the consequences of freezing (e.g., ice nucleation), causing the radial stem contraction evident in our data. The start of the shrinking period was linked to the day when peak growth occured, but finding a singular event causing the shrinking process to start proved difficult without significant connections with the first frost events or autumnal soil moisture declines. We concluded that surviving during extreme winters was the main principle governing E. hermaphroditum growth when existing at alpine ridge positions, causing unique adaptations to local micro-site conditions.

\section{Conclusions}

This study showed that high-precision dendrometers are suitable measuring instruments for identifying annual growth patterns in dwarf shrubs. For our focal species Empetrum hermaphroditum, the method yielded several novel insights into the phenology and growth physiology. From our analysis, we concluded that as an evergreen shrub at exposed and therefore mostly snow-free positions, E. hermaphroditum appeared capable of continuing photosynthetic activity throughout the year and to thus aggregate resources for use in early cell formation, as observed in other evergreen plants (Wyka and Oleksyn, 2014). This provided a competitive advantage over deciduous species in the same habitat, limiting the risk of losing resources through competition. To sustain the continued metabolism throughout the year, we found that E. hermaphroditum was highly dependent on available moisture, and thus, highly adapted to local microsite conditions. Furthermore, our findings confirmed the positive effects of temperatures on shoot growth in E. hermaphroditum to some extent (Chapin and Shaver, 1985; Shevtsova et al., 1997; Bråthen et al., 2018), yet, a clear link between near-surface thermal conditions and growth was lacking, with the overall growth mechanism defined by moisture availability and solar radiation. Hence, temperatures mainly play a role in freezing and thawing processes, on an intra-annual scale. We can thus confirm that while there is a link between shrub growth and warming conditions, it is most likely not uniform and highly variable over spatial and temporal scales (Elemendorf et al., 2012).

Overall, the fine-scale data provided by dendrometer measurements proved highly important, since it allowed for a detailed growth analysis, showing a growth mechanism, which is highly adapted to the local micro-environmental conditions at our studied exposed ridge positions, explaining the wide distribution and competitive ability of the species at these sites (Bienau et al., 2014; Bienau et al., 2016; Löffler and Pape, 2020) and highlighted the prominent role of the micro -environment in controlling growth processes (Zellweger et al., 2020). In a changing climatic regime, this might become a disadvantage, complicating adaptation to warming winters and longer snow-covered periods coupled with prolonged dry periods during summer (Hollesen et al., 2015; Weijers, Pape et al., 2018), which might cause early growth cessation. In accordance with previous studies (Milner et al., 2016; Virtanen et al., 2016; Wheeler et al., 2016; Saccone et al., 2017), our results suggested that winter conditions and altered snow regimes represented one of the most serious threats to evergreen shrub growth in 
https://doi.org/10.5194/bg-2021-99

Preprint. Discussion started: 10 May 2021

(C) Author(s) 2021. CC BY 4.0 License.

(c) (i)

480 tundra ecosystems. We conclude that because of the high local adaptation and dependency on specific winter radiation conditions and soil moisture availability of this species, E. hermaphroditum will not be able to persist at exposed positions in a changing climate or respond with longer periods of dormancy to warming conditions. This will potentially promote the spread of competing deciduous species and thus contribute to the arctic-alpine greening trend.

\section{Data availability}

485 All underlying data and statistical codes pertinent to the results presented in this publication will be made available in a data publication DOI in "ERDKUNDE---Archive for Scientific Geography" (https://www.erdkunde.uni-bonn.de).

\section{Author contribution}

JL had the idea, designed the research platform, conducted the field work, and together with RP ran the long-term project. SD analyzed the data, lead the writing of the manuscript and arranged the figures, with contributions from RP and JL.

\section{Competing interests}

The authors declare that they have no conflict of interest.

\section{Acknowledgements}

The authors thank Eike Albrecht, Niklas Beckers, Elise Dierking, Nils Hein, Stef Weijers, and Dirk Wundram for collaboration within our LTAER project, Ole Øvsteng and Anders Svare for hospitality, and both the landowners and 495 Norwegian authorities (Vågå and Stranda municipalities) for overall support. Parts of this study were supported by the Deutsche Forschungsgemeinschaft (DFG) (grants LO 830/16-1, LO 830/32-1).

\section{References}

Ackerman, D., Griffin, D., Hobbie, S. E., and Finlay, J. C.: Arctic shrub growth trajectories differ across soil moisture level s, Glob Chang Biol, 23, 4294-4302, doi:10.1111/gcb.13677, 2017.

500 Addis, C. E. and Bret-Harte, M. S.: The importance of secondary growth to plant responses to snow in the arctic, Funct Ecol, 33, 1050-1066, doi:10.1111/1365-2435.13323, 2019.

Aune, B.: National atlas of Norway: climate, Norwegian Mapping Authority, Hønefoss, Norway, 1993.

Bär, A., Bräuning, A., and Löffler, J.: Dendroecology of dwarf shrubs in the high mountains of Norway - A methodological approach, Dendrochronologia, 24, 17-27, doi:10.1016/j.dendro.2006.05.001, 2006. 
https://doi.org/10.5194/bg-2021-99

Preprint. Discussion started: 10 May 2021

(c) Author(s) 2021. CC BY 4.0 License.

\section{(c) (1)}

Bär, A., Bräuning, A., and Löffler, J.: Ring-width chronologies of the alpine dwarf shrub Empetrum hermaphroditum from the Norwegian mountains. IAWA J, 28, 325-338. doi:10.1163/22941932-90001644, 2007.

Bär, A., Pape, R., Bräuning, A., and Löffler, J.: Growth-ring variations of dwarf shrubs reflect regional climate signals in alpine environments rather than topoclimatic differences, $\mathrm{J}$ Biogeogr, 35, 625-636, doi:10.1111/j.13652699.2007.01804.x, 2008.

Bell, J. N. B. and Tallis, J. H.: Empetrum Nigrum L, J Ecol, 61, 289, doi:10.2307/2258934, 1973.

Belsley, D. A., Kuh, E., and Welsch, R. E.: Regression diagnostics: Identifying influential data and sources of collinearity / David A. Belsley, Edwin Kuh, Roy E. Welsch, Wiley series in probability and mathematical statistics, Wiley, New York, Chichester, 1980.

Bienau, M. J., Eckstein, R. L., Otte, A., and Durka, W.: Clonality increases with snow depth in the arctic dwarf shrub Empetrum hermaphroditum, Am J Bot, 103, 2105-2114, doi:10.3732/ajb.1600229, 2016.

Bienau, M. J., Hattermann, D., Kröncke, M., Kretz, L., Otte, A., Eiserhardt, W. L., Milbau, A., Graae, B. J., Durka, W., and Eckstein, R. L.: Snow cover consistently affects growth and reproduction of Empetrum hermaphroditum across latitudinal and local climatic gradients, Alp Bot, 124, 115-129, doi:10.1007/s00035-014-0137-8, 2014.

Blok, D., Sass-Klaassen, U., Schaepman-Strub, G., Heijmans, M. M. P. D., Sauren, P., and Berendse, F.: What are the main climate drivers for shrub growth in Northeastern Siberian tundra?, Biogeosci Discuss., 8, 771-799, doi:10.5194/bgd-8771-2011, 2011.

Blok, D., Weijers, S., Welker, J. M., Cooper, E. J., Michelsen, A., Löffler, J., and Elberling, B.: Deepened winter snow increases stem growth and alters stem $\delta 13 \mathrm{C}$ and $\delta 15 \mathrm{~N}$ in evergreen dwarf shrub Cassiope tetragona in high-arctic Svalbard tundra, Environ Res Lett, 10, 44008, doi:10.1088/1748-9326/10/4/044008, 2015.

Bråthen, K. A., Gonzalez, V. T., and Yoccoz, N. G.: Gatekeepers to the effects of climate warming? Niche construction restricts plant community changes along a temperature gradient, Perspect Plant Ecol Evol Syst, 30, 71-81, doi:10.1016/j.ppees.2017.06.005, 2018.

Breitsprecher, A. and Bethel, J. S.: Stem-Growth Periodicity of Trees in a Tropical Wet Forest of Costa Rica, Ecol, 71, 1156-1164, doi:10.2307/1937383, 1990.

530 Brodie, J. F., Roland, C. A., Stehn, S. E., and Smirnova, E.: Variability in the expansion of trees and shrubs in boreal Alas ka, Ecol, 100, e02660, doi:10.1002/ecy.2660, 2019.

Buchwal, A., Rachlewicz, G., Fonti, P., Cherubini, P., and Gärtner, H.: Temperature modulates intra-plant growth of Salix polaris from a high Arctic site (Svalbard), Polar Biol, 36, 1305-1318, doi:10.1007/s00300-013-1349-x, 2013.

Buras, A. and Wilmking, M.: Straight lines or eccentric eggs? A comparison of radial and spatial ring width measurements and its implications for climate transfer functions, Dendrochronologia, 32, 313-326, doi:10.1016/j.dendro.2014.07.002, 2014. 
https://doi.org/10.5194/bg-2021-99

Preprint. Discussion started: 10 May 2021

(c) Author(s) 2021. CC BY 4.0 License.

Carlson, B. Z., Corona, M. C., Dentant, C., Bonet, R., Thuiller, W., and Choler, P.: Observed long-term greening of alpine vegetation — a case study in the French Alps, Environ Res Lett, 12, 114006, doi:10.1088/1748 -9326/aa84bd, 2017.

Chan, T., Hölttä, T., Berninger, F., Mäkinen, H., Nöjd, P., Mencuccini, M., and Nikinmaa, E.: Separating water-potential induced swelling and shrinking from measured radial stem variations reveals a cambial growth and osmotic concentration signal, Plant Cell Environ, 39, 233-244, doi:10.1111/pce.12541, 2016.

Chapin, F. S., Sturm, M., Serreze, M. C., McFadden, J. P., Key, J. R., Lloyd, A. H., McGuire, A. D., Rupp, T. S., Lynch, A. H., Schimel, J. P., Beringer, J., Chapman, W. L., Epstein, H. E., Euskirchen, E. S., Hinzman, L. D., Jia, G., Ping, C.-L., Tape, K. D., Thompson, C. D. C., Walker, D. A., and Welker, J. M.: Role of land-surface changes in arctic summer warming, Sci, 310, 657-660, doi:10.1126/science.1117368, 2005.

Charra-Vaskou, K., Badel, E., Charrier, G., Ponomarenko, A., Bonhomme, M., Foucat, L., Mayr, S., and Améglio, T.: Cavitation and water fluxes driven by ice water potential in Juglans regia during freeze-thaw cycles, J Exp Bot, 67, 739750, doi:10.1093/jxb/erv486, 2016.

Chatterjee, S. and Price, B.: Regression Analysis by Example. John Wiley \& Sons, New York, ISBN 0-471-88479-0, 1977.

Choler, P.: Winter soil temperature dependence of alpine plant distribution: Implications for anticipating vegetation changes under a warming climate, Perspect Plant Ecol Evol Syst, 30, 6-15, doi:10.1016/j.ppees.2017.11.002, 2018.

Cooley, W. W. and Lohnes, P. R.: Multivariate data analysis, John Wiley \& Sons, New York, Chichester, 1971.

Dahl E.: Rondane, mountain vegetation in south Norway and its relation to the environment. Skrifter utgitt av det Norske Videnskaps-Akademi i Oslo, Mathematisk-Naturvidenskapelig Klasse, 3, 1-374, 1956.

Daubenmire, R. F.: An improved type of precision dendrometer, Ecol, 26, 97-98, 1945.

Deslauriers, A., Rossi, S., and Anfodillo, T.: Dendrometer and intra-annual tree growth: What kind of information can be inferred?, Dendrochronologia, 25, 113-124, doi:10.1016/j.dendro.2007.05.003, 2007.

Deslauriers, A., Rossi, S., Anfodillo, T., and Saracino, A.: Cambial phenology, wood formation and temperature thresholds in two contrasting years at high altitude in southern Italy, Tree Physiol, 28, 863-871, doi:10.1093/treephys/28.6.863, 2008.

Dolezal, J., Kurnotova, M., Stastna, P., and Klimesova, J.: Alpine plant growth and reproduction dynamics in a warmer world, New Phytol, doi:10.1111/nph.16790, 2020.

Drew, D. M. and Downes, G. M.: The use of precision dendrometers in research on daily stem size and wood property variation: A review, Dendrochronologia, 27, 159-172, doi:10.1016/j.dendro.2009.06.008, 2009.

Duchesne, L., Houle, D., and D’Orangeville, L.: Influence of climate on seasonal patterns of stem increment of balsam fir in a boreal forest of Québec, Canada, Agric For Meteorol, 162-163, 108-114, doi:10.1016/j.agrformet.2012.04.016, 2012.

Elmendorf, S. C., Henry, G. H. R., Hollister, R. D., Björk, R. G., Boulanger-Lapointe, N., Cooper, E. J., Cornelissen, J. H. C., Day, T. A., Dorrepaal, E., Elumeeva, T. G., Gill, M., Gould, W. A., Harte, J., Hik, D. S., Hofgaard, A., Johnson, D. R., Johnstone, J. F., Jónsdóttir, I. S., Jorgenson, J. C., Klanderud, K., Klein, J. A., Koh, S., Kudo, G., Lara, M., Lévesque, 
https://doi.org/10.5194/bg-2021-99

Preprint. Discussion started: 10 May 2021

(c) Author(s) 2021. CC BY 4.0 License.

\section{(c) (1)}

E., Magnússon, B., May, J. L., Mercado-Dı'az, J. A., Michelsen, A., Molau, U., Myers-Smith, I. H., Oberbauer, S. F., Onipchenko, V. G., Rixen, C., Martin Schmidt, N., Shaver, G. R., Spasojevic, M. J., Pórhallsdóttir, P. E., Tolvanen, A., Troxler, T., Tweedie, C. E., Villareal, S., Wahren, C.-H., Walker, X., Webber, P. J., Welker, J. M., and Wipf, S.: Plotscale evidence of tundra vegetation change and links to recent summer warming, Nat Clim Chang, 2, 453-457, doi:10.1038/nclimate1465, 2012.

Farrar, D. E. and Glauber, R. R.: Multicollinearity in regression analysis: the problem revisited, Rev Econ Stat, 92-107, 1967.

Fekedulegn, D., Mac Siurtain, M., and Colbert, J.: Parameter estimation of nonlinear growth models in forestry, Silva Fenn, 33, doi:10.14214/sf.653, 1999.

Francon, L., Corona, C., Till-Bottraud, I., Choler, P., Carlson, B. Z., Charrier, G., Améglio, T., Morin, S., Eckert, N., Roussel, E., Lopez-Saez, J., and Stoffel, M.: Assessing the effects of earlier snow melt-out on alpine shrub growth: The sooner the better?, Ecol Indic, 115, 106455, doi:10.1016/j.ecolind.2020.106455, 2020.

Frindte, K., Pape, R., Werner, K., Löffler, J., and Knief, C.: Temperature and soil moisture control microbial community composition in an arctic-alpine ecosystem along elevational and micro-topographic gradients, The ISME J, 13, 20312043, doi:10.1038/s41396-019-0409-9, 2019.

585 Fritts, H.: Tree Rings and Climate, Elsevier Science, Oxford, 583 pp., 1976.

Gimeno, T. E., Camarero, J. J., Granda, E., Pías, B., and Valladares, F.: Enhanced growth of Juniperus thurifera under a warmer climate is explained by a positive carbon gain under cold and drought, Tree Physiol, 32, 326-336, doi:10.1093/treephys/tps011, 2012.

González-Rodríguez, Á. M., Brito, P., Lorenzo, J. R., Gruber, A., Oberhuber, W., and Wieser, G.: Seasonal cycles of sap flow and stem radius variation of Spartocytisus supranubius in the alpine zone of Tenerife, Canary Islands, Alp Botany, 127, 97-108, doi:10.1007/s00035-017-0189-7, 2017.

Gough, L., Bass, H., and McLaren, J. R.: Effects of Increased Soil Nutrients on Seed Rain: A Role for Seed Dispersal in the Greening of the Arctic?, Arct Antarct Alp Res, 47, 27-34, doi:10.1657/AAAR0014-055, 2015.

Graae, B. J., Vandvik, V., Armbruster, W. S., Eiserhardt, W. L., Svenning, J.-C., Hylander, K., Ehrlén, J., Speed, J. D.M., Klanderud, K., Bråthen, K. A., Milbau, A., Opedal, Ø. H., Alsos, I. G., Ejrnæs, R., Bruun, H. H., Birks, H. J. B., Westergaard, K. B., Birks, H. H., and Lenoir, J.: Stay or go - how topographic complexity influences alpine plant population and community responses to climate change, Perspect Plant Ecol Evol Syst, 30, 41-50, doi:10.1016/j.ppees.2017.09.008, 2018.

Heide, O. M.: Physiological aspects of climatic adaptation in plants with special reference to high-latitude environments, in: A. Kaurin, O. Junttila, \& J. Nilsen (Eds.), Plant production in the North: Proceedings from Plant Adaptation Workshop. Tromsö: Norwegian University Press, 1-22, 1985. 
https://doi.org/10.5194/bg-2021-99

Preprint. Discussion started: 10 May 2021

(c) Author(s) 2021. CC BY 4.0 License.

\section{(c) (1)}

Hein, N., Pape, R., Finch, O.-D., and Löffler, J.: Alpine activity patterns of Mitopus morio (Fabricius, 1779) are induced by variations in temperature and humidity at different scales in central Norway, J Mt Sci, 11, 644-655, doi:10.1007/s11629013-2913-0, 2014.

Hollesen, J., Buchwal, A., Rachlewicz, G., Hansen, B. U., Hansen, M. O., Stecher, O., and Elberling, B.: Winter warming as an important co-driver for Betula nana growth in western Greenland during the past century, Glob Chang Biol, 21, 24102423, doi:10.1111/gcb.12913, 2015.

Imdad M. U., Aslam M., Altaf S. A. M.: Some new diagnostics of multicollinearity in linear regression model, Sains Malays, 48, 2051-2060. doi:10.17576/jsm-2019-4809-26, 2019.

Ježík, M., Blaženec, M., Kučera, J., Strelcová, K., and Ditmarová, L.: The response of intra-annual stem circumference increase of young European beech provenances to 2012-2014 weather variability, Iforest, 9, 960-969, doi:10.3832/ifor1829-009, 2016.

Kleiven, M.: Studies on the xerophile vegetation in northern Gudbrandsdalen, Norway, Nytt Mag Bot, 7, 1-60, 1959.

Köcher, P., Horna, V., and Leuschner, C.: Environmental control of daily stem growth patterns in five temperate broadleaved tree species, Tree Physiol, 32, 1021-1032, doi:10.1093/treephys/tps049, 2012.

Körner, C. and Kèorner, C.: Alpine Plant Life: Functional Plant Ecology of High Mountain Ecosystems, 2nd edition, Springer Berlin Heidelberg; Imprint; Springer, Berlin, Heidelberg, 349 pp., 2003.

Körner, C.: Paradigm shift in plant growth control, Curr Opin Plant Biol, 25, 107-114, doi:10.1016/j.pbi.2015.05.003, 2015.

Körner, C. and Hiltbrunner, E.: The 90 ways to describe plant temperature, Perspect Plant Ecol Evol Syst, 30, 16-21, doi:10.1016/j.ppees.2017.04.004, 2018.

Körner, C. and Paulsen, J.: A world-wide study of high altitude treeline temperatures, J Biogeogr, 31, 713-732, doi:10.1111/j.1365-2699.2003.01043.x, 2004.

Kovàcs, P., Petres, T., and Tóth, L.: A New Measure of Multicollinearity in Linear Regression Models, Int Stat Rev, 73, 405-412, doi:10.1111/j.1751 -5823.2005.tb00156.x, 2005.

Kuprian, E., Briceño, V. F., Wagner, J., and Neuner, G.: Ice barriers promote supercooling and prevent frost injury in reproductive buds, flowers and fruits of alpine dwarf shrubs throughout the summer, Environ Exp Bot, 106, 4-12, doi:10.1016/j.envexpbot.2014.01.011, 2014.

Le Moullec, M., Buchwal, A., Wal, R., Sandal, L., and Hansen, B. B.: Annual ring growth of a widespread high arctic shrub reflects past fluctuations in community-level plant biomass, J Ecol, 107, 436 -451, doi:10.1111/1365-2745.13036, 2019.

Li, X., Rossi, S., Liang, E., and Julio Camarero, J.: Temperature thresholds for the onset of xylogenesis in alpine shrubs on the Tibetan Plateau, Trees, 30, 2091-2099, doi:10.1007/s00468-016-1436-z, 2016.

Liang, E., Lu, X., Ren, P., Li, X., Zhu, L., and Eckstein, D.: Annual increments of juniper dwarf shrubs above the tree line on the central Tibetan Plateau: a useful climatic proxy, Ann Bot, 109, 721 -728, doi:10.1093/aob/mcr315, 2012. 
https://doi.org/10.5194/bg-2021-99

Preprint. Discussion started: 10 May 2021

(c) Author(s) 2021. CC BY 4.0 License.

Liu, X., Nie, Y., and Wen, F.: Seasonal dynamics of stem radial increment of Pinus taiwanensis Hayata and its response to environmental factors in the Lushan Mountains, Southeastern China, Forests, 9, 387, doi:10.3390/f9070387, 2018.

Löffler, J.: Micro-climatic determination of vegetation patterns along topographical, altitudinal, and oceanic-continental gradients in the high mountains of Norway, Erdkunde, 57, 232-249, doi:10.3112/erdkunde.2003.03.05, 2003.

Löffler, J.: Snow cover dynamics, soil moisture variability and vegetation ecology in high mountain catchments of cen tral Norway, Hydrol Process, 19, 2385-2405, doi:10.1002/hyp.5891, 2005.

Löffler, J.: The influence of micro -climate, snow cover, and soil moisture on ecosystem functioning in high mountains, J Geogr Sci, 17, 3-19, doi:10.1007/s11442-007-0003-3, 2007.

Löffler, J. and Finch, O.-D.: Spatio-temporal Gradients between High Mountain Ecosystems of Central Norway, Arct Antarct Alp Res, 37, 499-513, doi:10.1657/1523-0430(2005)037[0499:SGBHME]2.0.CO;2, 2005.

Löffler, J. and Pape, R.: Thermal niche predictors of al pine plant species, Ecol, e02891, doi:10.1002/ecy.2891, 2020.

Löffler, J., Pape, R., and Wundram, D.: The climatologic significance of topography, altitude and region in high mountains A survey of oceanic-continental differentiations of the Scandes, Erdkunde, 60, 15-24, doi:10.3112/erdkunde.2006.01.02, 2006.

Macias-Fauria, M., Forbes, B. C., Zetterberg, P., and Kumpula, T.: Eurasian Arctic greening reveals teleconnections and the potential for structurally novel ecosystems, Nat Clim Chang, 2, 613-618, doi:10.1038/NCLIMATE1558, 2012.

Milner, J. M., Varpe, Ø., van der Wal, R., and Hansen, B. B.: Experimental icing affects growth, mortality, and flowering in a high Arctic dwarf shrub, Ecol Evol, 6, 2139-2148, doi:10.1002/ece3.2023, 2016.

Moen, A. and Lillethun, A.: National atlas of Norway: vegetation, Norwegian Mapping Authority, 1999.

Myers-Smith, I. H., Forbes, B. C., Wilmking, M., Hallinger, M., Lantz, T., Blok, D., Tape, K. D., Macias-Fauria, M., SassKlaassen, U., Lévesque, E., Boudreau, S., Ropars, P., Hermanutz, L., Trant, A., Collier, L. S., Weijers, S., Rozema, J., Rayback, S. A., Schmidt, N. M., Schaepman-Strub, G., Wipf, S., Rixen, C., Ménard, C. B., Venn, S., Goetz, S., AndreuHayles, L., Elmendorf, S., Ravolainen, V., Welker, J., Grogan, P., Epstein, H. E., and Hik, D. S.: Shrub expansion in tundra ecosystems: dynamics, impacts and research priorities, Environ Res Lett, 6, 45509, doi:10.1088/17489326/6/4/045509, 2011.

Myers-Smith, I. H., Hallinger, M., Blok, D., Sass-Klaassen, U., Rayback, S. A., Weijers, S., J. Trant, A., Tape, K. D., Naito,

A. T., Wipf, S., Rixen, C., Dawes, M. A., A. Wheeler, J., Buchwal, A., Baittinger, C., Macias-Fauria, M., Forbes, B. C., Lévesque, E., Boulanger-Lapointe, N., Beil, I., Ravolainen, V., and Wilmking, M.: Methods for measuring arctic and alpine shrub growth: A review, Earth Sci Rev, 140, 1-13, doi:10.1016/j.earscirev.2014.10.004, 2015.

Myers-Smith, I. H., Kerby, J. T., Phoenix, G. K., Bjerke, J. W., Epstein, H. E., Assmann, J. J., John, C., And reu-Hayles, L., Angers-Blondin, S., Beck, P. S. A., Berner, L. T., Bhatt, U. S., Bjorkman, A. D., Blok, D., Bryn, A., Christiansen, C. T., 665 Cornelissen, J. H. C., Cunliffe, A. M., Elmendorf, S. C., Forbes, B. C., Goetz, S. J., Hollister, R. D., Jong, R. de, Loranty, M. M., Macias-Fauria, M., Maseyk, K., Normand, S., Olofsson, J., Parker, T. C., Parmentier, F.-J. W., Post, E., 
https://doi.org/10.5194/bg-2021-99

Preprint. Discussion started: 10 May 2021

(c) Author(s) 2021. CC BY 4.0 License.

\section{(c) (1)}

Schaepman-Strub, G., Stordal, F., Sullivan, P. F., Thomas, H. J. D., Tømmervik, H., Treharne, R., Tweedie, C. E., Walker, D. A., Wilmking, M., and Wipf, S.: Complexity revealed in the greening of the Arctic, Nat Clim Chang, 10, 106-117, doi:10.1038/s41558-019-0688-1, 2020.

Neuner, G.: Frost resistance in alpine woody plants, Front Plant Sci, 5, 654, doi:10.3389/fpls.2014.00654, 2014.

Ögren, E.: Effects of climatic warming on cold hardiness of some northern woody plants assessed from simulation experiments, Physiol Plant, 112, 71-77, doi:10.1034/j.1399-3054.2001.1120110.x, 2001.

Pape, R., Wundram, D., and Löffler, J.: Modelling near-surface temperature conditions in high mountain environments: an appraisal, Clim Res, 39, 99-109, doi:10.3354/cr00795, 2009.

Polunin, N.: Attempted Dendrochronological Dating of Ice Island T-3, Sci, 122, 1184-1186, doi:10.1126/science.122.3181.1184, 1955

Preece, C., Callaghan, T. V., and Phoenix, G. K.: Impacts of winter icing events on the growth, phenology and physiology of sub-arctic dwarf shrubs, Physiol Plant, 146, 460-472, doi:10.1111/j.1399-3054.2012.01640.x, 2012.

R Developement Core Team 2020. R: A language and environment for statistical computing. Vienna, Austria: R Foundation for Statistical Computing, https://www.R-project.org.

Reineke, L. H.: A precision dendrometer, J Forest, 30, 692-697, 1932.

Ropars, P., Lévesque, E., and Boudreau, S.: How do climate and topography influence the greening of the forest-tundra ecotone in northern Québec? A dendrochronological analysis of Betula glandulosa, J Ecol, 103, 679-690, doi:10.1111/1365-2745.12394, 2015.

Rossi, S., Deslauriers, A., and Morin, H.: Application of the Gompertz equation for the study of xylem cell development, Dendrochronologia, 21, 33-39, doi:10.1078/1125-7865-00034, 2003.

Rossi, S., Deslauriers, A., Anfodillo, T., Morin, H., Saracino, A., Motta, R., and Borghetti, M.: Conifers in cold environments synchronize maximum growth rate of tree-ring formation with day length, New Phytol, 170, 301-310, doi:10.1111/j.1469-8137.2006.01660.x, 2006.

690 Rossi, S., Deslauriers, A., Anfodillo, T., and Carraro, V.: Evidence of threshold temperatures for xylogenesis in conifers at high altitudes, Oecologia, 152, 1-12, doi:10.1007/s00442-006-0625-7, 2007.

Rossi, S., Deslauriers, A., Griçar, J., Seo, J.-W., Rathgeber, C. B. K., Anfodillo, T., Morin, H., Levanic, T., Oven, P., and Jalkanen, R.: Critical temperatures for xylogenesis in conifers of cold climates, Glob Ecol Biogeogr, 17, 696-707, doi:10.1111/j.1466-8238.2008.00417.x, 2008.

695 Saccone, P., Hoikka, K., and Virtanen, R.: What if plant functional types conceal species-specific responses to environment? Study on arctic shrub communities, Ecol, 98, 1600-1612, doi:10.1002/ecy.1817, 2017.

Scherrer, D. and Körner, C.: Topographically controlled thermal-habitat differentiation buffers alpine plant diversity against climate warming, J Biogeogr, 38, 406-416, doi:10.1111/j.1365-2699.2010.02407.x, 2011. 
https://doi.org/10.5194/bg-2021-99

Preprint. Discussion started: 10 May 2021

(c) Author(s) 2021. CC BY 4.0 License.

(c) (i)

Schmidt, N. M., Baittinger, C., Kollmann, J., and Forchhammer, M. C.: Consistent Dendrochronological Response of the Dioecious Salix arctica to Variation in Local Snow Precipitation across Gender and Vegetation Types, Arct Antarct Alp Res, 42, 471-475, doi:10.1657/1938-4246-42.4.471, 2010.

Shaver, G. R. and III, F. S. C.: Effect of Fertilizer on Production and Biomass of Tussock Tundra, Alaska, U.S.A, Arct Alp Res, 18, 261, doi:10.2307/1550883, 1986.

Shetti, R.: Methods in shrub dendro-ecology: Understanding the processes influencing shrub growth in the Arctic and Alpine ecosystems, PhD-Thesis, Mathematisch-Naturwissenschaftlichen Fakultät, 209 pp., 2018.

Shevtsova, A., Haukioja, E., and Ojala, A.: Growth Response of Subarctic Dwarf Shrubs, Empetrum nigrum and Vaccinium vitis-idaea, to Manipulated Environmental Conditions and Species Removal, Oikos, 78, 440, doi:10.2307/3545606, 1997.

Smiljanić, M. and Wilmking, M.: Drivers of stem radial variation and its pattern in peatland Scots pines: A pilot study, Dendrochronologia, 47, 30-37, doi:10.1016/j.dendro.2017.12.001, 2018.

Starr, G. and Oberbauer, S. F.: Photosynthesis of arctic evergreens under snow: Implications for tundra ecosystem carbon balance, Ecol, 84, 1415-1420, doi:10.1890/02-3154, 2003.

Steppe, K., Sterck, F., and Deslauriers, A.: Diel growth dynamics in tree stems: linking anatomy and ecophysiology, Trends Plant Sci, 20, 335-343, doi:10.1016/j.tplants.2015.03.015, 2015.

Stocker, T.: Climate change 2013: The physical science basis Working Group I contribution to the Fifth assessment report of the Intergovernmental Panel on Climate Change / edited by Thomas F. Stocker, Working Group I co-chair, University of Bern [and nine others], Cambridge University Press, New York, 2014.

Sturm, M., Racine, C., and Tape, K.: Climate change. Increasing shrub abundance in the Arctic, Nature, 411, 546-547, doi:10.1038/35079180, 2001.

Stushnoff, C. and Junttila, O.: Seasonal development of cold stress resistance in several plant species at a coastal and a continental location in North Norway, Polar Biol, 5, 129-133, doi:10.1007/BF00441691, 1986.

Theil H.: Applied economic forecasting. Study in Mathematics \& Managerial Economics, North-Holland Publishing Company, Amsterdam, 1971.

Tian, Q., He, Z., Xiao, S., Du, J., Peng, X., Lin, P., and Ding, A.: Effects of artificial warming on stem radial changes in Qinghai spruce saplings in the Qilian Mountains of China, Dendrochronologia, 55, 110-118, doi:10.1016/j.dendro.2019.04.009, 2019.

Van der Maaten-Theunissen, M., Kahle, H.-P., and van der Maaten, E.: Drought sensitivity of Norway spruce is higher than that of silver fir along an altitudinal gradient in southwestern Germany, Ann For Sci, 70, 185 -193, doi:10.1007/s13595012-0241-0, 2013.

Van der Maaten, E., van der Maaten-Theunissen, M., Smiljanić, M., Rossi, S., Simard, S., Wilmking, M., Deslauriers, A.,

Fonti, P., Arx, G. v., and Bouriaud, O.: dendrometeR: Analyzing the pulse of trees in R, Dendrochronologia, 40, 12-16, doi:10.1016/j.dendro.2016.06.001, 2016. 
https://doi.org/10.5194/bg-2021-99

Preprint. Discussion started: 10 May 2021

(c) Author(s) 2021. CC BY 4.0 License.

\section{(c) (1)}

Van der Maaten, E., Pape, J., van der Maaten-Theunissen, M., Scharnweber, T., Smiljanic, M., Cruz-García, R., and Wilmking, M.: Distinct growth phenology but similar daily stem dynamics in three co-occurring broadleaved tree species, Tree Physiol, 38, 1820-1828, doi:10.1093/treephys/tpy042, 2018.

735 Van der Wal, R. and Stien, A.: High-arctic plants like it hot: a long-term investigation of between-year variability in plant biomass, Ecol, 95, 3414-3427, doi:10.1890/14-0533.1, 2014.

Virtanen, R., Oksanen, L., Oksanen, T., Cohen, J., Forbes, B. C., Johansen, B., Käyhkö, J., Olofsson, J., Pulliainen, J., and Tømmervik, H.: Where do the treeless tundra areas of northern highlands fit in the global biome system: toward an ecologically natural subdivision of the tundra biome, Ecol Evol, 6, 143-158, doi:10.1002/ece3.1837, 2016.

740 Vowles, T. and Björk, R. G.: Implications of evergreen shrub expansion in the Arctic, J Ecol, 107, 650-655, doi:10.1111/1365-2745.13081, 2019.

Weijers, S., Broekman, R., and Rozema, J.: Dendrochronology in the High Arctic: July air temperatures reconstructed from annual shoot length growth of the circumarctic dwarf shrub Cassiope tetragona, Quat Sci Rev, 29, 3831-3842, doi:10.1016/j.quascirev.2010.09.003, 2010.

Weijers, S., Beckers, N., and Löffler, J.: Recent spring warming limits near-treeline deciduous and evergreen alpine dwarf shrub growth, Ecosphere, 9, e02328, doi:10.1002/ecs2.2328, 2018a.

Weijers, S., Pape, R., Löffler, J., and Myers-Smith, I. H.: Contrasting shrub species respond to early summer temperatures leading to correspondence of shrub growth patterns, Environ Res Lett, 13, 34005, doi:10.1088/1748-9326/aaa5b8, 2018b.

Weijers, S., Buchwal, A., Blok, D., Löffler, J., and Elberling, B.: High Arctic summer warming tracked by increased Cassiope tetragona growth in the world's northernmost polar desert, Glob Chang Biol, 23, 5006-5020, doi:10.1111/gcb.13747, 2017.

Weijers, S., and Löffler, J.: Auswirkungen des Klimawandels auf das Wachstum von Zwergsträuchern in Hochgebirgen, in: Warnsignal Klima: Hochgebirge im Wandel, edited by: Lozán, J. L., Breckle, S.-W., Grassl, H., Kasang, D., Paul, F., and Schickhoff, U., Wissenschaftliche Auswertungen, Hamburg, Germany, 23 -27, 2020.

Wheeler, J. A., Cortés, A. J., Sedlacek, J., Karrenberg, S., van Kleunen, M., Wipf, S., Hoch, G., Bossdorf, O., and Rixen, C.: The snow and the willows: earlier spring snowmelt reduces performance in the low-lying alpine shrub Salix herbacea, $\mathrm{J}$ Ecol, 104, 1041-1050, doi:10.1111/1365-2745.12579, 2016.

Wilmking, M., Hallinger, M., van Bogaert, R., Kyncl, T., Babst, F., Hahne, W., Juday, G. P., Luis, M. d., Novak, K., and Völlm, C.: Continuously missing outer rings in woody plants at their distributional margins, Dendrochronologia, 30, 213-222, doi:10.1016/j.dendro.2011.10.001, 2012.

Wundram, D., Pape, R., and Löffler, J.: Alpine Soil Temperature Variability at Multiple Scales, Arct Antarct Alp Res, 42(1), 117-128, doi:10.1657/1938-4246-42.1.117, 2010.

Wyka, T. P. and Oleksyn, J.: Photosynthetic ecophysiology of evergreen leaves in the woody angiosperms - a review, Dendrobiology, 72, 3-27, doi:10.12657/denbio.072.001, 2014. 
https://doi.org/10.5194/bg-2021-99

Preprint. Discussion started: 10 May 2021

(c) Author(s) 2021. CC BY 4.0 License.

(c) (1)

765 Zellweger, F., Frenne, P. de, Lenoir, J., Vangansbeke, P., Verheyen, K., Bernhardt-Römermann, M., Baeten, L., Hédl, R., Berki, I., Brunet, J., van Calster, H., Chudomelová, M., Decocq, G., Dirnböck, T., Durak, T., Heinken, T., Jaroszewicz, B., Kopecký, M., Máliš, F., Macek, M., Malicki, M., Naaf, T., Nagel, T. A., Ortmann-Ajkai, A., Petř́k, P., Pielech, R., Reczyńska, K., Schmidt, W., Standovár, T., Świerkosz, K., Teleki, B., Vild, O., Wulf, M., and Coomes, D.: Forest microclimate dynamics drive plant responses to warming, Sci, 368, 772-775, doi:10.1126/science.aba6880, 2020.

770 Zweifel, R., Zimmermann, L., Zeugin, F., and Newbery, D. M.: Intra-annual radial growth and water relations of trees: implications towards a growth mechanism, J Exp Bot, 57, 1445-1459, doi:10.1093/jxb/erj125, 2006.

Zweifel, R., Drew, D. M., Schweingruber, F., and Downes, G. M.: Xylem as the main origin of stem radius changes in Eucalyptus, Funct Plant Biol, 41, 520-534, doi:10.1071/FP13240, 2014.

Zweifel, R.: Radial stem variations - a source of tree physiological information not fully exploited yet, Plant Cell Environ, 39, 231-232, doi:10.1111/pce.12613, 2016. 
https://doi.org/10.5194/bg-2021-99

Preprint. Discussion started: 10 May 2021

(c) Author(s) 2021. CC BY 4.0 License.

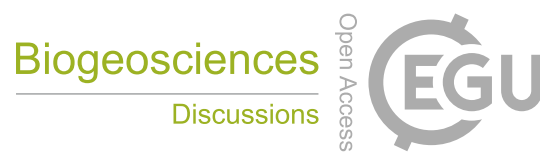

(c) (i)

\section{Appendix A}

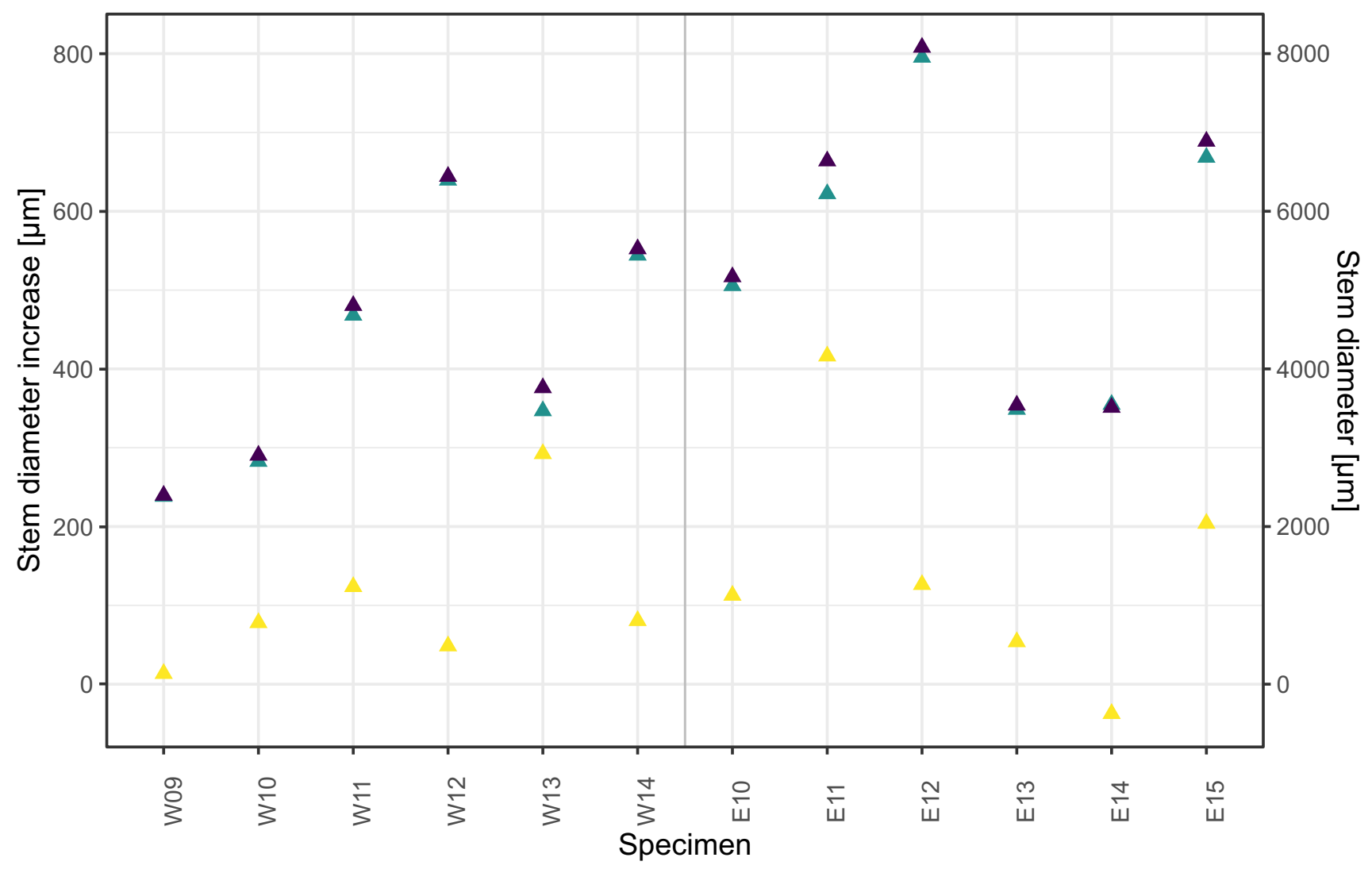

$\Delta$ final $\Delta$ initial $\Delta$ Total stem change

Figure A1: Summary of stem diameter variation observed for the 12 monitored specimens across the two study regions (West and East). 
https://doi.org/10.5194/bg-2021-99

Preprint. Discussion started: 10 May 2021

(c) Author(s) 2021. CC BY 4.0 License. (a)

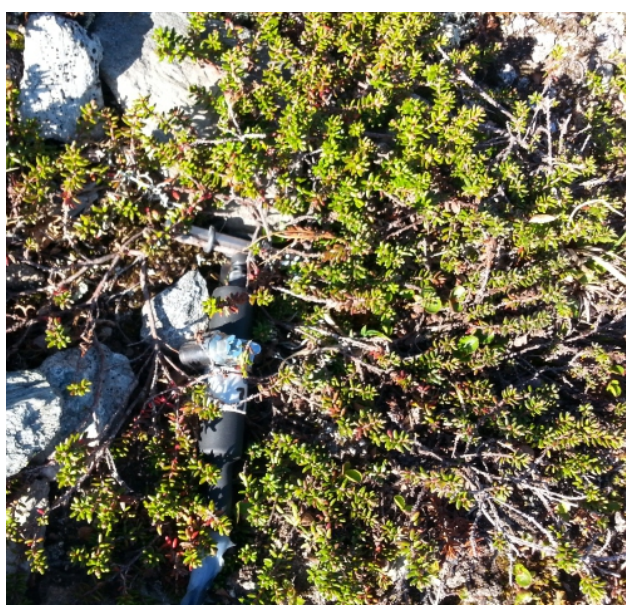

(b)

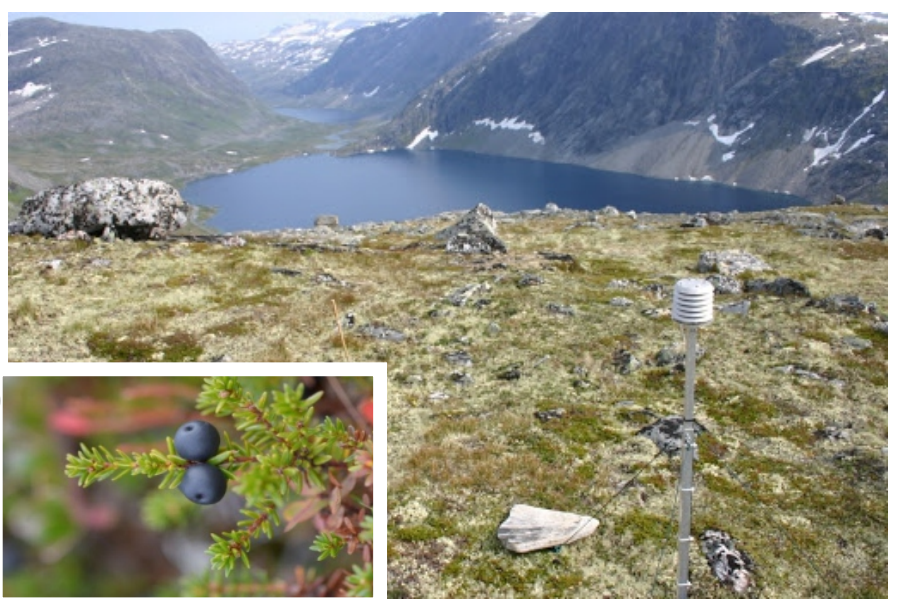

Figure A2: Dendrometer set up (a), the studied species $E$. hermaphroditum in the studied region in Central Norway (b), and the species fruits and leafs (c). 
https://doi.org/10.5194/bg-2021-99

Preprint. Discussion started: 10 May 2021

(c) Author(s) 2021. CC BY 4.0 License.
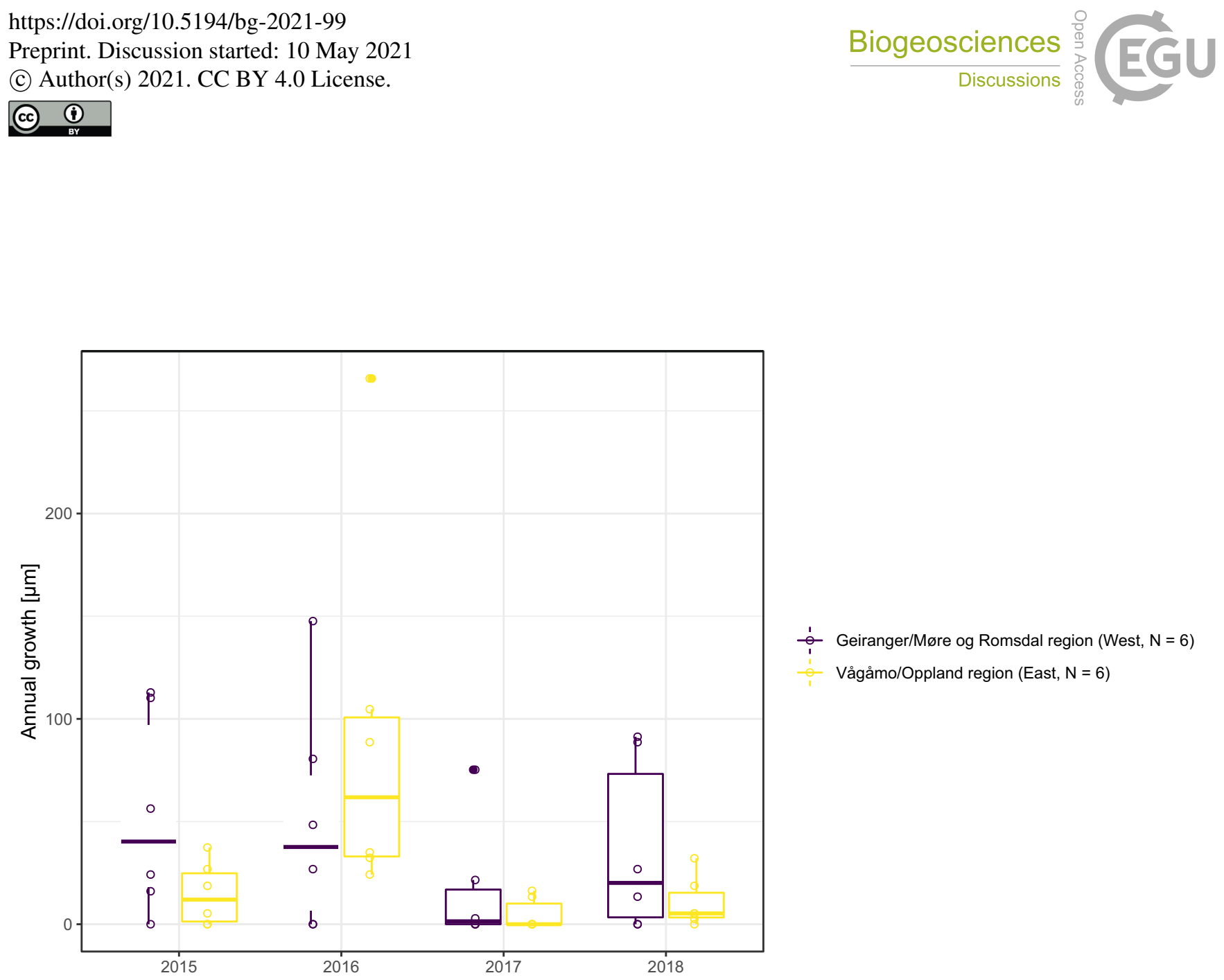

Figure A3: Boxplots of observed annual growth within each of the two study regions (Vågåmo/Oppland region $($ East, $\mathrm{N}=6$ ) and Geiranger/Møre og Romsdal region (West, $\mathrm{N}=6$ )). 
https://doi.org/10.5194/bg-2021-99

Preprint. Discussion started: 10 May 2021

(c) Author(s) 2021. CC BY 4.0 License.

(c) (i)

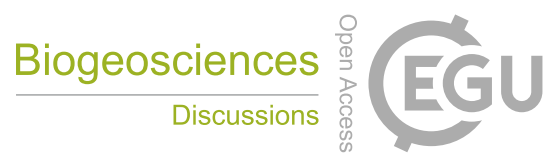

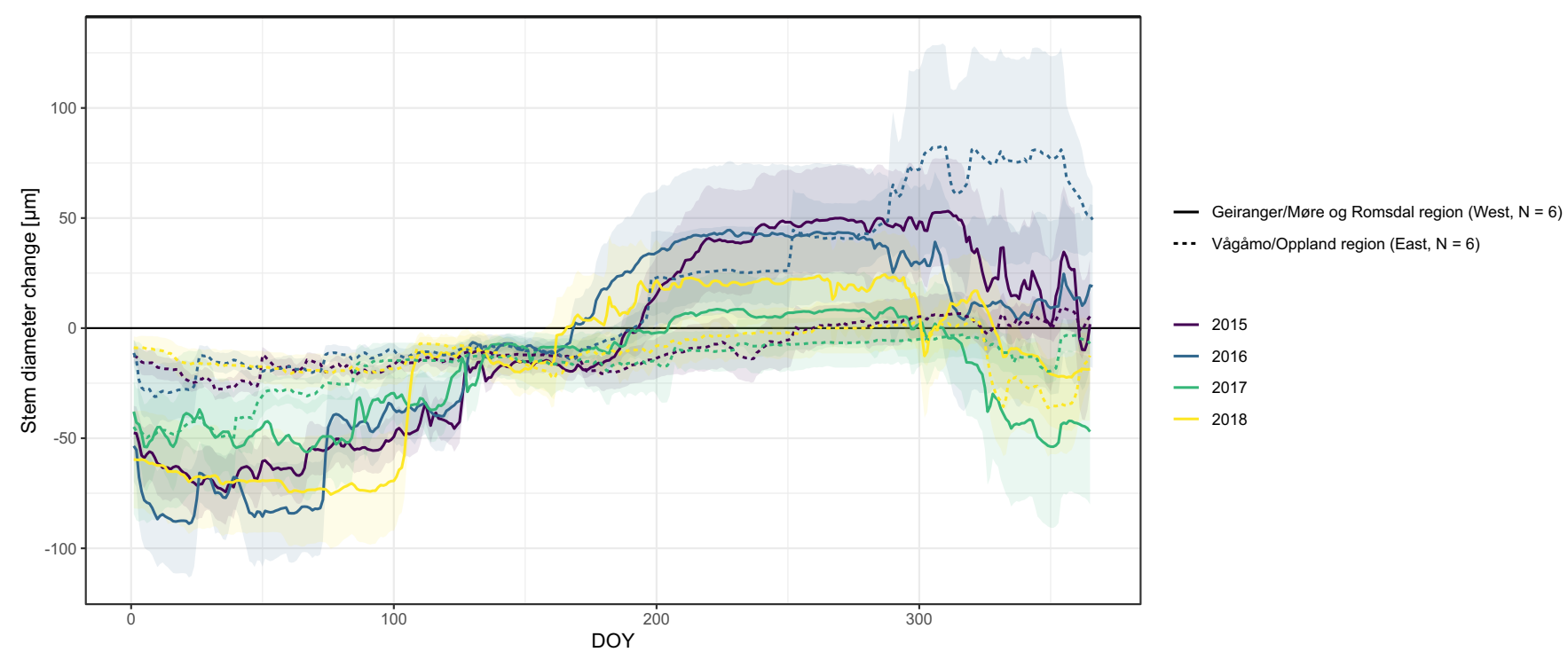

Figure A4: Observed stem diameter change averaged over the monitored specimens within each of the two study regions

(Vågåmo/Oppland region (East, $\mathrm{N}=6$ ) and Geiranger/Møre og Romsdal region (West, $\mathrm{N}=6$ )). Transparency indicates standard deviation. 
https://doi.org/10.5194/bg-2021-99

Preprint. Discussion started: 10 May 2021

(c) Author(s) 2021. CC BY 4.0 License.

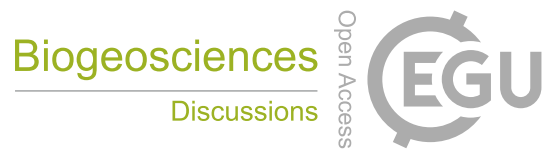

(c) (i)

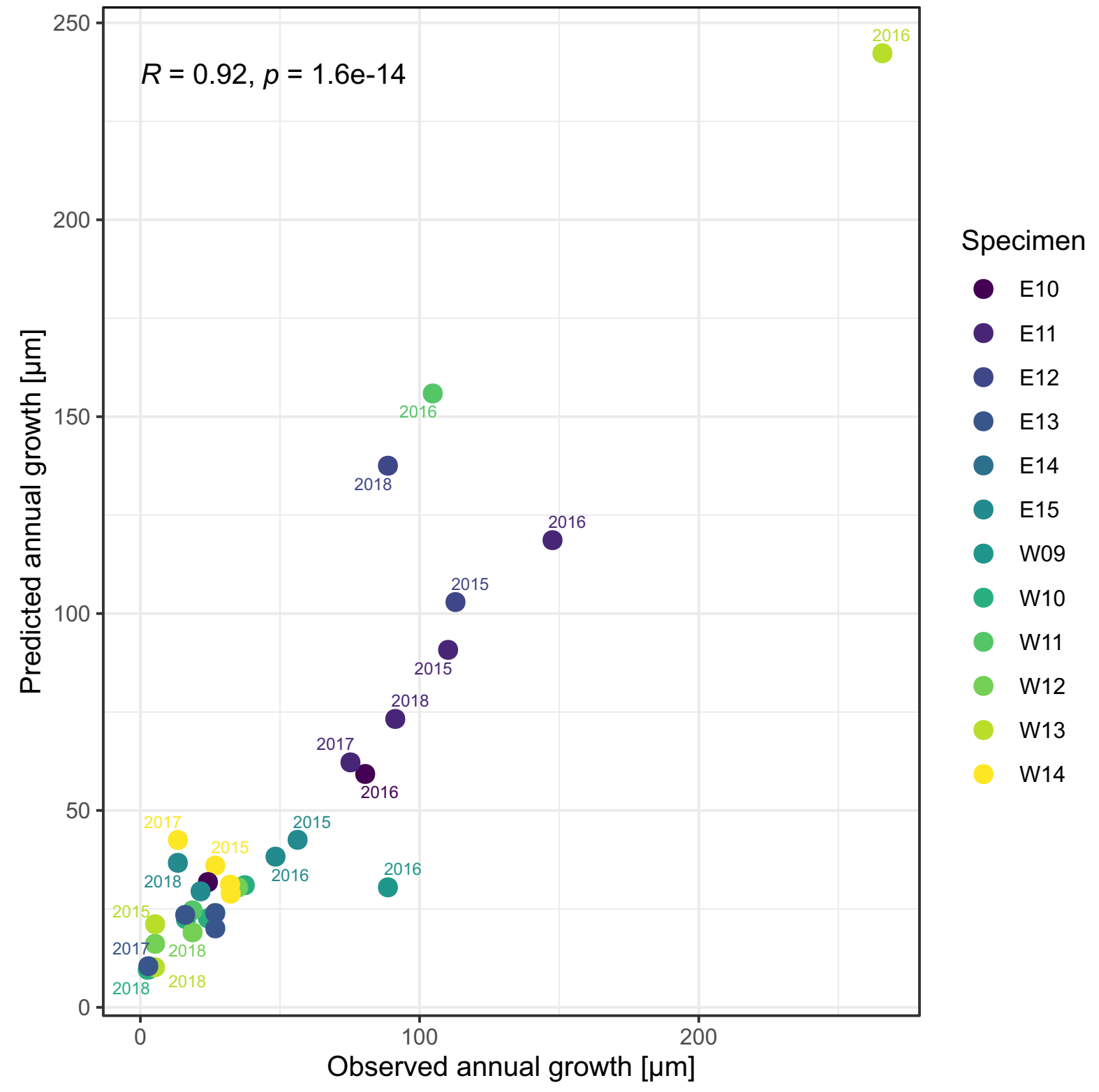

Figure A5: Observed annual growth and annual growth predicted by a linear regression model including timing (growth initiation and growth cessation), as well as peak growth as independant variables. Colours indicate the monitored specimens at the individual sites (E

= East, $\mathrm{W}=$ West, numbers indicate elevation $(100 \mathrm{~m}$ a. s. 1.). 
https://doi.org/10.5194/bg-2021-99

Preprint. Discussion started: 10 May 2021

(c) Author(s) 2021. CC BY 4.0 License.

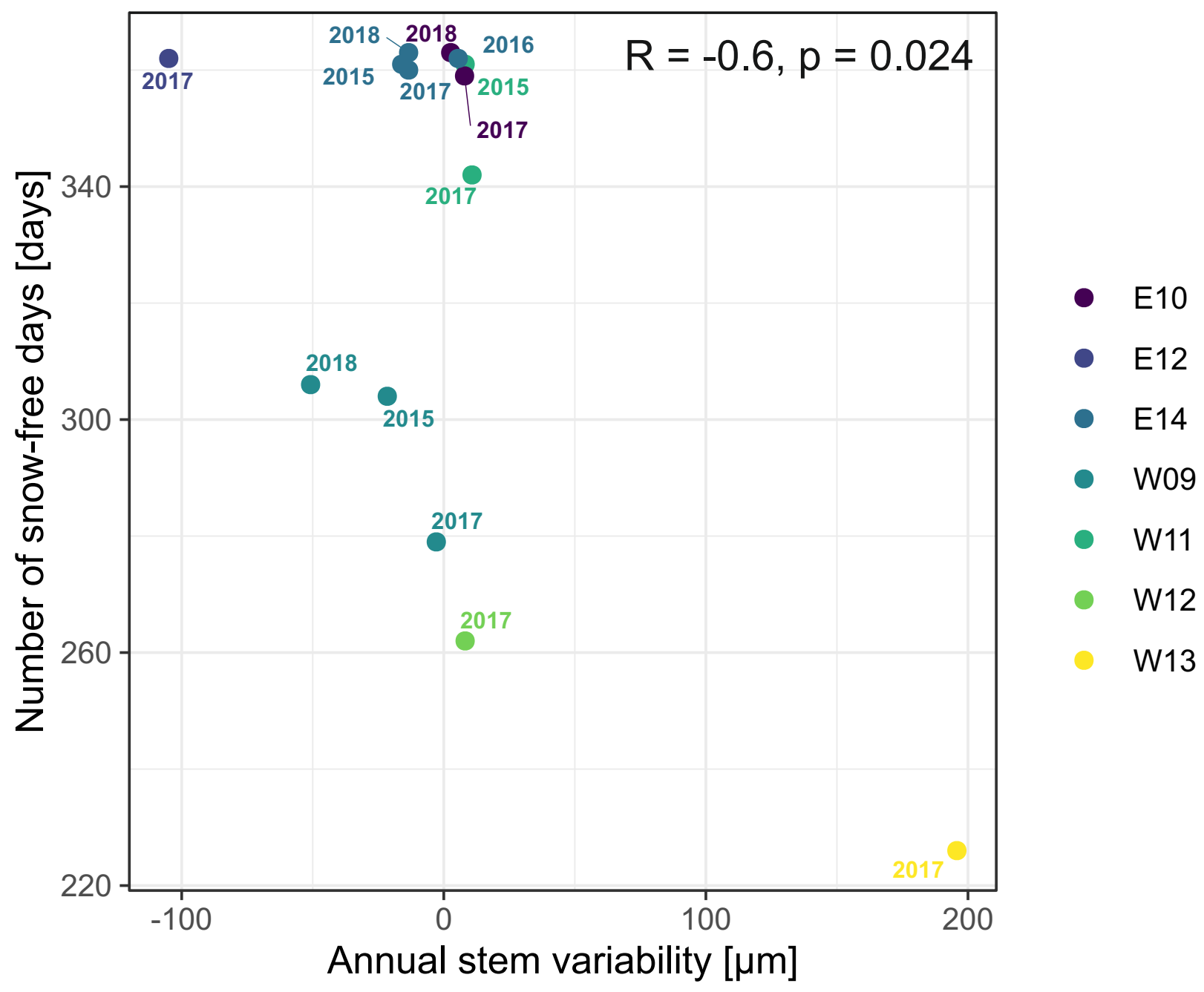

Figure A6: Number of snow-free days and annual stem diameter variability in years in which no irreversible growth occurred (total annual growth $=0)$. Colours indicate the monitored specimens at the individual sites $(E=E a s t, W=$ West, numbers indicate elevation (100 m a. s. 1.). 